\title{
Steady flow in contracted and expanded rectangular channels
}

\author{
Some considerations concerning \\ the shape of the water surface
}

\author{
BY Frank ENGELUND aND .JoHs. MUNCH-PETERSEN \\ HYDRAULC LABORATORIES, TECHNICAL UNIVERSITY OF DENMARK
}

Texte français, p. 475.

\begin{abstract}
The hypotheses are a horizontal rectangular canal, incompressible fluid, potential flou and linear theory; superficial current and air entrainment are neglected. Development of the general equation of the free surface from Laplace's equation. Discussion of various expressions of the Mach angle in relation to the Froude number and the relatine depth. Application, with experimental control, to the case of a symmetrical converging canal, and then to that of a diverging canal, in saper-critical flow.
\end{abstract}

SYMBOLS

0 velocity potential.

$\bar{\nu}=$ velocity' vector.

$\nu=$ magnitude of velocity.

$v_{x,}, v_{i l}, v_{z}=$ velocity components.

$v_{m}=$ mean velocity of the cross-section.

$y_{0}=$ ordinate of the water surface.

$y_{\prime \prime \prime}=$ mean depth.

$y_{1}=$ critical depth.

$y=$ acceleration of gravity $\left(9.82 \mathrm{~m} / \mathrm{s}^{2}\right)$.

$\mathrm{F}=\frac{v_{m}}{\sqrt{g y_{m}}}=$ Froude number.

$H=$ specific head.

$$
\begin{aligned}
b & =\text { width of chamnel. } \\
n & =\text { integer. } \\
\lambda_{n} & =\text { wave lengths. } \\
a_{n} & =\text { amplitudes. }
\end{aligned}
$$

$\theta=$ angle between disturbance-lines and channel walls.

$\nabla=$ operator Nabla.

From the hydraulic research of the last decades it is well known that the water surface in high-velocity flows is often more of less irregular and undulated. If the cross-section is changed (transition) or the channel is curved 
this will cause the formation of a standingwave pattern, as shown in Fig. 1. The waves are in this case caused by a channel expansion.

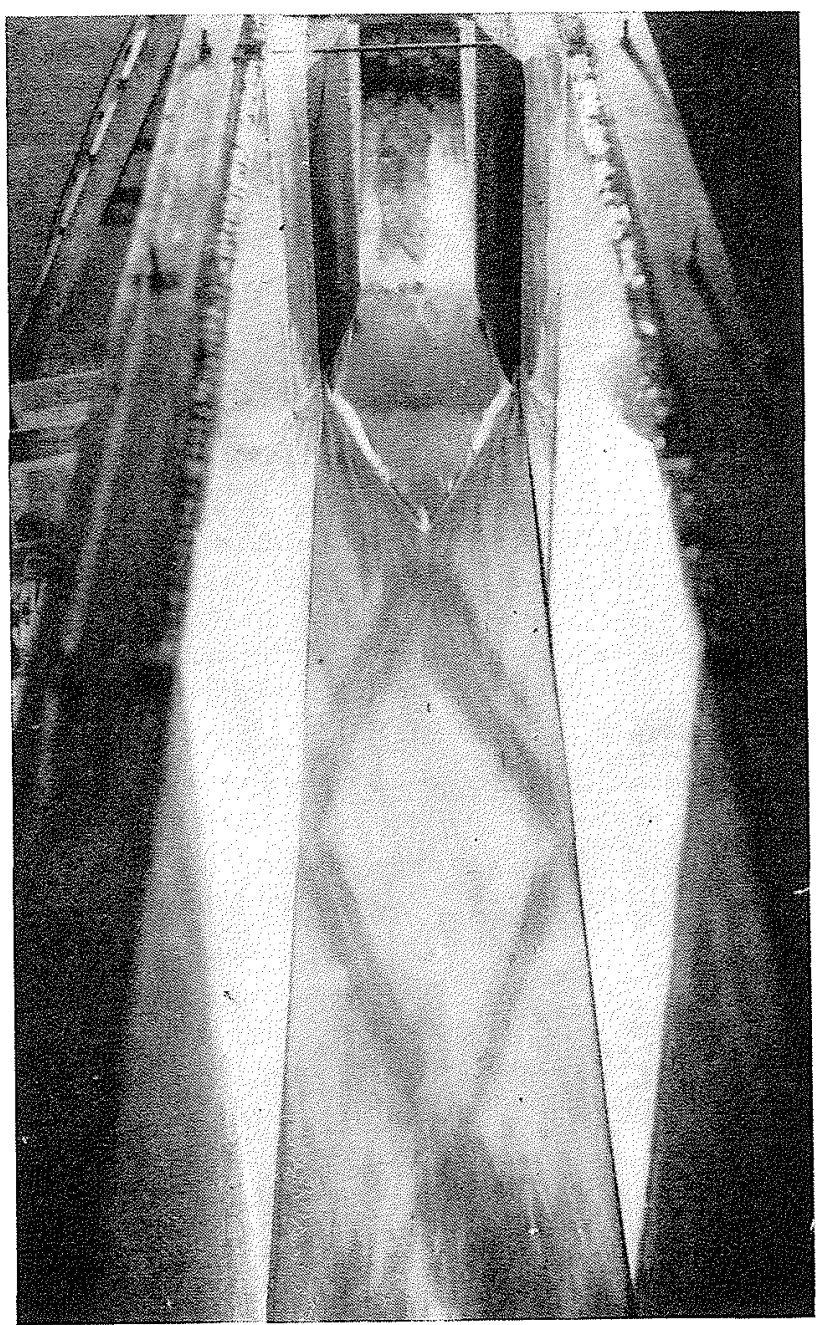

Fig. 1.

It has been proved that a high-velocity flow (which corresponds to relatively great values of the Froude number $\mathrm{F}=\frac{v_{m}}{\sqrt{g y_{m}}}$ ) is analogous to the supersonic flow of gases. This analogy has often been mentioned and applied in the literature. Comprehensive accounts of these investigations have been given by A.T. IPPEN a.o. in [1] and [2], where further references may be found.

In order to characterize the waves we introduce the angle $\theta$ between the waves and the lateral boundaries of the chamnel. It is stated that 0 -for small amplitudes-may be computed from the formula :

$$
\sin \theta=\frac{1}{\mathrm{~F}}=\frac{\sqrt{g y_{m}}}{v_{m}}
$$

This expression is quite analogous to the one used for fixing the Mach angle in supersonic flow. The expression (1) can be generalized to comprise waves of finite amplitudes. All these considerations have been checked by a great number of experiments.

While the expression (1) can, no doubt, be applied in most cases of high-velocity flow, several observations tend to indicate that it must fail when the Froude number approaches unity. On the whole (1) ean only be said to make sense when $F>1$, that is, in supercritical flow, but the undermentioned measurements of the flow in a Venturi flume has shown that waves of the same nature may exist around critieal depth, that is, for $\mathbf{F}=1$ and even for Froude numbers smaller than unity. Further (1) is not satisfactory even in a high-velocity flow unless the width of the channel is great in comparison with the depth $y_{m}$.

Evidently a generalisation is needed, and the present paper deals with an attempt at developing a more general theory, capable of giving a description of all the observed data.

\section{THE FUNDAMENTAL THEORY.}

The subsequent deductions are based on the following assumptions, the applicability of which will be discussed later.

1) The flow is supposed to take place in a horizontal channel of rectangular cross-section. A Cartesian coordinate system is applied, the $x$-axis being horizontal in the longitudinal direction of the channel, the $y$-axis vertical upward, and the $z$-axis perpendicular to the channel walls (see Fig. 7).

2) The flow is supposed to be a potential flow of an incompressible fluid. This implies negligence of the friction, a fact which will be accounted for in greater detail in a subsequent section.

If the velocity potential is denoted as $\varphi$, we have :

$$
\begin{gathered}
\bar{v}=-\nabla \varphi \\
\text { or } \quad v_{x}=-\frac{\partial \varphi}{\partial x}, \quad v_{l \prime}=-\frac{\partial \varphi}{\partial y}, \quad v_{z}=--\frac{\partial \varphi}{\partial z}(2)
\end{gathered}
$$

The incompressibility is iexpressed in the equation of continuity :

$$
\nabla \cdot \bar{v}=\frac{\partial v_{x}}{\partial x}+\frac{\partial v_{u}}{\partial y}+\frac{\partial v_{z}}{\partial z}=0
$$


This, in conjunction with (2) leads to LAPLACE's equation :

$$
\frac{\partial^{2} p}{\partial x^{2}}+\frac{\partial^{2} \varphi}{\partial y^{2}}+\frac{\partial^{2} p}{\partial z^{2}}=0
$$

3) It is supposed that the relative deviations from the mean depth are so small that the square and higher powers can be neglected. The question is thus of a linear theory. Yet, the experiments menlioned in the following seem to indicate that rather appreciable deviations from the mean depth can be tolerated.

4) The effects of the surface tension and possible air entrainment are neglected.

Let us consider first a simple symmetrical flow, i.e., a flow symmetrical about the verlical plane $z=(1 / 2) b$. A simple particular solulion of (3) is given by :

$$
c \cdot \cosh \left(2 \pi y \sqrt{\left.\frac{1}{b^{2}}+\frac{1}{\lambda^{2}}\right) \cdot \cos \frac{2 \pi x}{\lambda} \cdot \cos \frac{2 \pi z}{b}(4)}\right.
$$

where $v_{m}$ is the mean velocily of the flow, $b$ the width of the channel, , the wave length of the standing wave, and $c$ an arbitrary constant. Next, we shall show that the boundary condilions can be fulfilled by (4).

The first condition to be fulfilled is that the velocity along the channel boundaries must have no component perpendicular to these, that is :

$$
\begin{aligned}
& v_{z}=-\frac{\partial o}{\partial z}=0 \text { for } z=0 \text { and } z=b \\
& v_{n}=-\frac{\partial \theta}{\partial y}=0 \text { for } y=0
\end{aligned}
$$

It will be seen that (4) fulfills those conditions aulomalieally. To be able to express a third condition we have to deduce first an expression for the water surface. To this end we develop the equations:

$$
v_{x}=-\frac{\partial \varphi}{\partial x}=v_{m}+
$$

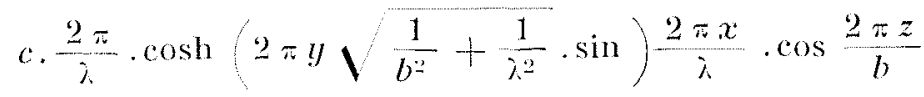
$v_{v}^{2} \cong b^{2}=b_{m}^{2}+2 v_{m} \cdot c \cdot \frac{2 \pi}{\lambda}$

$\cosh \left(2 \pi y \sqrt{\frac{1}{b}+\frac{1}{b^{2}}}\right) \cdot \sin \frac{2 \pi x}{\lambda} \cdot \cos \frac{2 \pi z}{b}$ terms of the second order in $c$ being neglected.

Let $y_{0}$ denote the ordinate of and $y_{0}$ the veloeity at a point of the water surface. H being the head, we have:

$$
\mathrm{H}=y_{0}+\frac{\nu_{10}^{2}}{2 g}
$$

Substituting the above expression for $v^{2}$, we obtain :

$$
\begin{aligned}
& y_{0}=\left(\mathrm{H}-\frac{v_{m}^{2}}{2 g}\right)-2 \pi c \cdot \frac{v_{m}}{g \lambda} \\
& \cosh \left(2 \pi y_{m} \sqrt{\left.\frac{1}{b^{2}}+\frac{1}{\lambda^{2}}\right) \cdot \sin \frac{2 \pi x}{\lambda} \cdot \cos \frac{2 \pi z}{b}}\right.
\end{aligned}
$$

OI :

$$
y_{0}=y_{m}+a \cdot \sin \frac{2 \pi x}{\lambda} \cos \frac{2 \pi z}{b}
$$

where $y_{m}$ denotes the mean depth and $a$ the amplitude.

A third boundary condition is to be expressed mathematically, namely the one that, at every point of the water surface, the velocity vector $\tilde{u}=\left(v_{x}, v_{y}, v_{z}\right)$ must be a tangent to the water surface or, what amounts to the same thing: i) must be perpendicular to the normal of the water surface at this point.

The tangent plane at a point of the water surface may be defined by two linearly independent vectors $F_{1}$ and $F_{2}$ both tangents to the water surface. Two such vectors are for instance:

$$
F_{1}=\left(1, \frac{\partial y_{0}}{\partial x}, 0\right) \text { and } \bar{F}_{2}=\left(0, \frac{\partial y_{0}}{\partial z}, 1\right)
$$

$A$ vector $\pi$ in the direction of the normal is given by the vector product of these, i.e. :

$$
\bar{n}=\overline{\mathrm{F}}_{1} \times \overline{\mathrm{F}}_{2}=\left\{\frac{\partial y_{0}}{\partial x^{\prime}},-1, \frac{\partial y_{0}}{\partial z}\right\}
$$

Now we are able to express the third boundary condition, realizing that the scalar product of $\bar{v}$ and $\pi$ inust vamish :

$$
\bar{v} \cdot \bar{n}=0=\frac{\partial y_{0}}{\partial x} \cdot v_{x}-v_{y}+\frac{\partial y_{0}}{\partial z} \cdot v_{z}
$$

The last term of this equation is of the second order in $c$ and may therefore be neglected. 'The condition will then be :

$$
\frac{\partial y_{0}}{\partial x} \cdot v_{i t}-v_{y}=0
$$

for $y=y_{0}$. Substituting in this equation the expressions (2), (4), and (5), we find that the third boundary condition is satisfied if :

$\frac{4 \pi^{2}}{\lambda^{2}} \cdot \frac{b_{m}^{2}}{g}=2 \pi \sqrt{\frac{1}{b^{2}}}+\frac{1}{\lambda^{2}} \cdot \tanh \left(2 \pi y_{m} \sqrt{\frac{1}{b^{2}}+\frac{1}{\lambda^{2}}}\right)$ 
Next, we observe that the equation (5) of the water surface can be written as :

$y_{1}=y_{m}+\frac{1}{2} a\left[\sin 2 \pi\left(\frac{x}{\lambda}+\frac{z}{b}\right)+\sin 2 \pi\left(\frac{x}{\lambda}-\frac{z}{b}\right)\right]$

from which it is obvious that the 'characteristies' are given by :

$$
\frac{x}{i}+\frac{z}{b}=\text { const. and } \frac{x}{i}-\frac{z}{b}=\text { const. }
$$

The angle 0 between these disturbance lines and the channel walls is consequently determined by :

$$
\tan 0=\frac{b}{\lambda}
$$

from which we get :

$$
\sqrt{\frac{1}{b^{2}}+\frac{1}{\lambda^{2}}}=\frac{1}{b \cos \theta}
$$

Substituting this expression in Eq. (6), we obtain :

$$
\sin \theta=\frac{\sqrt{g y_{m}}}{v_{m}} \cdot \sqrt{\frac{\operatorname{linh}\left(\frac{2 \pi y_{m} \cdot \frac{1}{b} \cdot \cos \theta}{2 \pi y_{m}} \cdot \frac{1}{b} \cdot \cos \theta\right.}{2}(7)}
$$

where $\frac{\sqrt{g ! I_{m}}}{D_{m}}$ is equal to $1 / \mathrm{F} . \mathrm{Eq} .(7)$ is the desired generalization of (1).

For sufficiently small values of the parameter $p=2 \pi y_{m} / b$ the following approximate equation must hold :

$$
\tanh \left[\begin{array}{cc}
2 \pi y_{m}, & 1 \\
b & \cos \theta
\end{array}\right]=\frac{2 \pi y_{m}, \ldots 1}{b}, \frac{1}{\cos 0}
$$

so that Eq. (7) is practically identical with (1).

For sufficiently sireal values of $\frac{2}{b} y_{m}$ we get

$$
\tanh \left(\frac{2 \pi y_{m}}{b} \cdot \frac{1}{\cos \theta}\right) \cong 1
$$

By substitution hereol and of the relations $b \cos \theta=\lambda \sin \theta$ into $(7)$, this is reduced to :

$$
\sin 0=\left(\sqrt{\frac{g i}{2 \pi}} \cdot \frac{1}{v_{m}}\right)^{2}
$$

It is interesting to note that $\sqrt{\frac{g^{2}}{2 \pi}}$ is the expression for the celerity of a deep-water wave, just as $\sqrt{g y_{m}}$ is the usual expression for the celerity of shallow-water waves.

Provided that $\mathrm{F}$ and the parameter $p=2 \pi y_{m} / b$ are known, 0 can be computed from $\mathrm{E}_{\mathrm{g}}$. (7) by trial and error, but it is easier - and usually sufficiently accurate - to use the diagram illustrited in Fig. 2.

The solution given by (4), (5) and (7) is, however, not the only one fulfilling the boundary conditions. If in (4) we had inserted the lactor $\cos (4 \pi z / b)$ instead of $\cos (2 \pi z / b)$ we should still have the same boundary conditions fulfilled. To realize this it is not necessary to carry out the computations in detail. All we need do is to let $b / 2$ replace $b$ in all the previous expressions. The new solution will correspond to a different wave length and to a different angle 0 , which we may obtain from the diagram in Fig. 2,

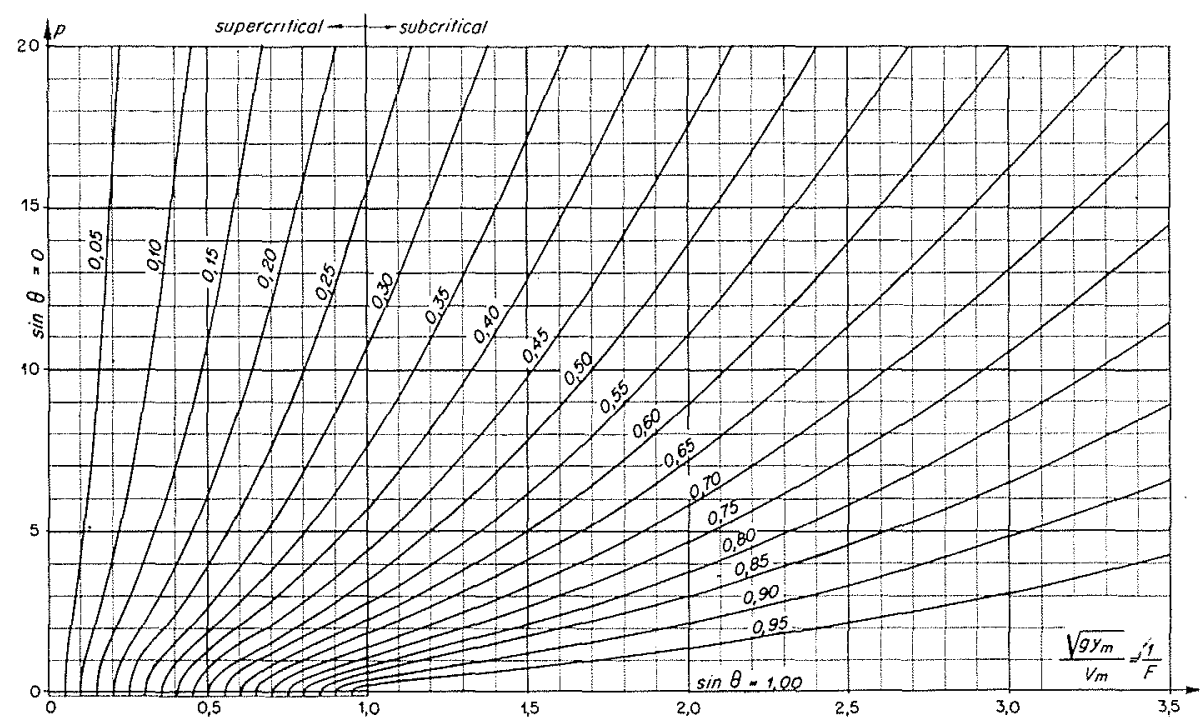

FIG. 2. 
using the parameter $p=4 \pi y_{m} / b$ instead of $p=2 \pi y_{m} / b$ used in the previous case.

An infinite number of solutions can be obtained by applying the factor $\cos (n \pi z / b)$ in $(5)$. Symmetrical flow corresponds to even values of $n$. The corresponding value of the wave length can be estimated from the diagram Fig. 2 by applying $p=\pi n y_{m} / b$. To make a distinction between the different solutions we shall talk about "waves of the $n^{\text {th }}$ order". "The corresponding wave lengths and wave angles are denoted by $\lambda_{n}$ and $\theta_{n}$, respectively.

It is important to note that-within the limits of a first-order theory (i.e. when higher powers of the amplitudes can be neglected)- new solutions can be obtained by addition of the individual particular solutions. Consequently (5) can be generalized and a quite general expression for the water surface is given as a Founien series :

$$
y_{0}=y_{m}+\sum_{n} a_{n} \cdot \sin \frac{2 \pi}{\lambda_{n}}\left(x_{n}+\delta_{n}\right) \cdot \cos \frac{n \pi z}{b}
$$

THE CONDITIONS WITH A SYMMETRICAL CHANNEL CONTRACTION.

(Venturi flumes, etc.)

Equation (8) shows that the water surface may be considered as a superposition of an in-
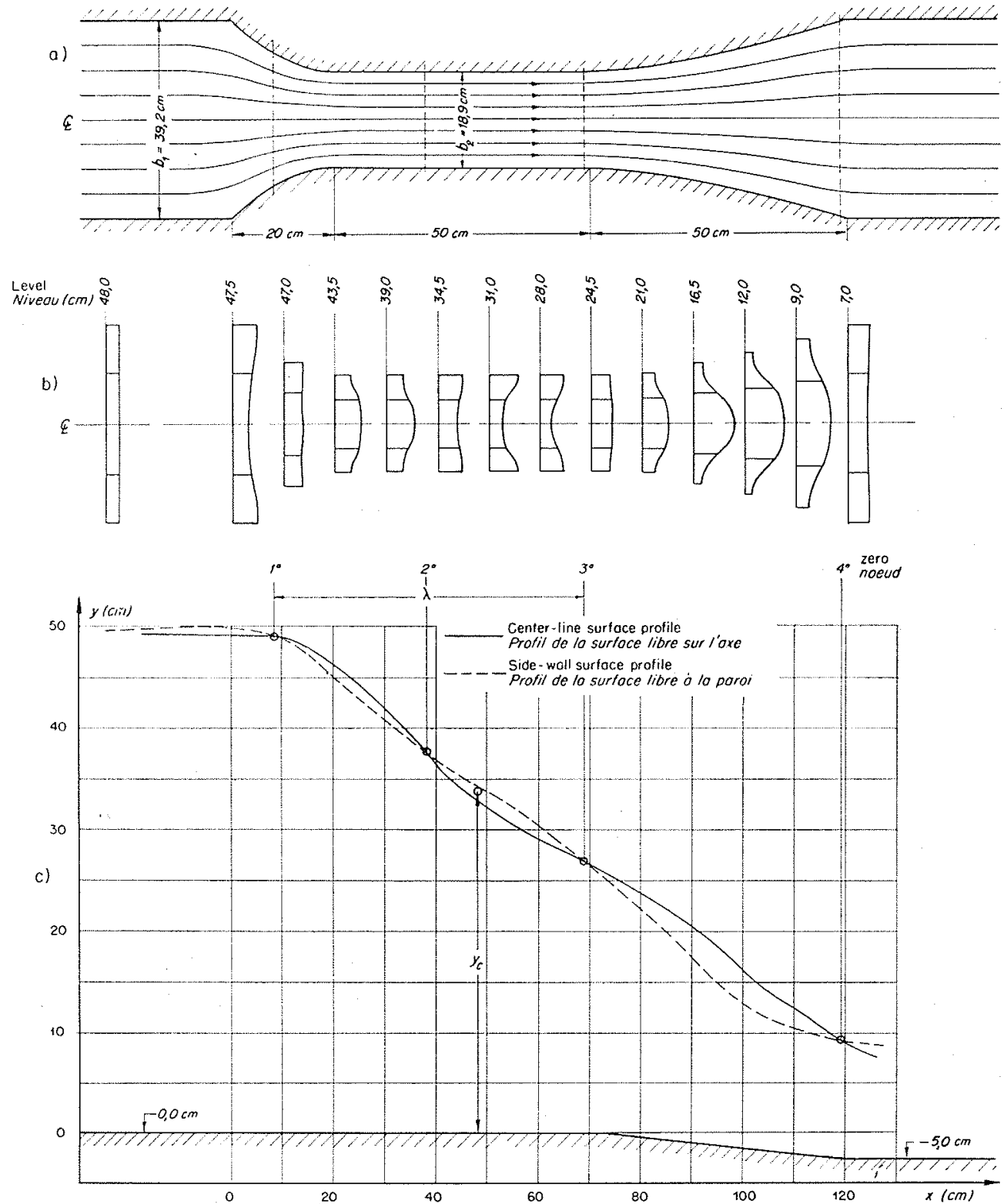

Fig. 3.

Experiment $n^{\circ} 8 .-Q=0.1164 \mathrm{~m}^{3} / \mathrm{s}-y_{c}=33,7 \mathrm{~cm}-\lambda$ (measured) $=60.4 \mathrm{~cm}$ Essai $\mathrm{n}^{\circ} 8 .-\mathrm{Q}=0,1164 \mathrm{~m}^{3} / \mathrm{s}-y_{0}=33,7 \mathrm{~cm}-\lambda$ (mesuré) $=60,4 \mathrm{~cm}$ 
finity of standing waves whose angle $\theta_{n}$ with the side walls decreases with increasing $n$.

Owing to the symmetry, only even values of $n$ can be used, but it is not possible to predict the shape of the water surface in detail as the different amplitudes $a_{2}, a_{4} \ldots a_{n}$ are unknown beforehand. With a channel contraction, however, the amplitudes generally decrease very quickly with increasing $n$, so that the angle 0 of the resulting wave does not deviate very much from the value determined for $n=2$. If the contraction is essential (in the present case the contraction ratio is about $2: 1$ ) the experiments show that even a fairly even transition gives an appreciable disturbance that can be considered, practically speaking, as a pure second-order wave.

This is illustrated in Fig. 3, showing the measurement of the water surface through a Venturi flume carried out with a point gauge with $1 \mathrm{~cm}$ divisions and $1 \mathrm{~mm}$ estimate.

At the transition from the parallel flow in the admission channel to the inlet, the stream lines bend towards the central plane (Fig. $3 a$, $x=$ about 0 ). This requires an overpressure at the channel sides, which is produced by a higher water level at the walls and a lower water level in the middle of the channel. For $x$ about $10 \mathrm{~cm}$ the stream lines have a flex tangent, indicated as $1^{\text {st }}$ zero, after which they bend away from the central plane. Accordingly the cross-section of the water surface has its maximum at the middle. At the outlet analogous conditions prevail. The cross-sections (Fig. $3 b$ ) show that the surface profiles in transversal direction may be represented by cosinusoids. From Fig. $3 c$ it will be seen that the surface oscillations in the longitudinal direction along the walls as well as at the middle are approximately sinusoids. 'This makes it likely that the water surface may be computed from the diagram applying $1 / F$ and $p=2 \pi y_{m} / b$. In the plot of the water surface, $\lambda$ is measured as the distance between $1^{\text {st }}$ zero and $3^{\text {ra }}$ zero. The corresponding value of $y_{m}$ is put equal to $y$, and accordingly $F=1$. The measurements show that in the proximity of $2^{\text {nd }}$ zero we may put $y_{m}=y_{c}$. A more careful analysis of the water surface has shown that, on account of the slope and the curvature of the water surface in a vertical plane, the minimum of the specific head and the corresponding depth $y_{m}=y_{c}$ are situated in the parallel portion of the throat and not at the end of it. Furthermore, that $y$ is still equal to $\% \mathrm{H}$, because the average water surface has a flex tangent for $y_{m}=y_{c}$, so that the effect of the curvature is inessential.

The validity of the above theory has been checked by a series of experiments $\left(^{\star}\right)$ in a Venturi flume with horizontal bottom shown in Fig. 3. The results appear from Table I.

\section{TABLE I}

\begin{tabular}{|c|c|c|c|c|c|c|c|}
\hline & & & & & \multicolumn{3}{|c|}{$F=1$} \\
\hline$\dot{\bar{x}}^{2} z$ & $\begin{array}{l}x \text { in } \\
1^{\text {st }}\end{array}$ & $\begin{array}{l}m \text { for } \\
2^{\text {nit }}\end{array}$ & $\begin{array}{l}\text { zeros } \\
3^{\text {ra }}\end{array}$ & $<\stackrel{\dot{g}}{\mathscr{E}}$ & $2_{\pi ! l_{c}} b$ & 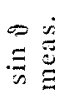 & 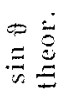 \\
\hline 1 & 12.1 & 30.0 & 47.1 & 35.0 & 3.26 & 0.48 & 0.52 \\
\hline 2 & 11.5 & 32.9 & 48.3 & $\mathrm{ab}, 37.0$ & 3.71 & 0.46 & 0.49 \\
\hline 3 & 12.1 & 32.2 & 51.0 & 38.9 & 3.82 & 0.44 & 0.48 \\
\hline 4 & 12.0 & 32.6 & 54.4 & +2.4 & 4.55 & 0.41 & 0.43 \\
\hline 5 & 12.2 & 32.2 & 60.4 & 48.2 & 5.50 & 0.37 & 0.41 \\
\hline 6 & 10.6 & 35.0 & 60.0 & 49.4 & 6.67 & 0.36 & 0.38 \\
\hline 7 & 10.0 & 32.3 & 61.5 & 51.5 & 7.87 & 0.35 & 0.35 \\
\hline 8 & 11.3 & 38.5 & 63.9 & 52.6 & 8.75 & 0.34 & 0.33 \\
\hline 9 & 11.1 & 38.2 & 65.2 & 54.1 & 9.53 & 0.33 & 0.32 \\
\hline 10 & 8.5 & 37.8 & 68.8 & 60.3 & 11.2 & 0.30 & 0.29 \\
\hline 11 & 9.4 & 38.4 & 72.1 & 62.7 & 12.8 & 0.29 & 0.28 \\
\hline 12 & 13.8 & 45.6 & 72.7 & 58.9 & 13.8 & 0.30 & 0.27 \\
\hline 13 & 14.4 & 46.3 & 77.4 & 63.0 & 17.5 & 0.29 & 0.23 \\
\hline
\end{tabular}

It will be seen that $1^{\text {st }}$ zero is fixed for $x=$ about $10 \mathrm{~cm}$, i.e., at the middle of the throat, and that $2^{\text {nd }}$ and 3 rd zeros move a little downstream with increasing discharge, but not farther than to allow their locations still to be in accordance with the above considerations concerning the locations of the zeros and the origin of the waves. Besides, the position and the curvature of the water surface must be assumed to have a close connection with the location of $y_{c}$ and the zero's, and with the relation between $F$, $2 \pi y_{m} / b$ and $\lambda$.

Further, a series of experiments have been carried out in a smaller flume with adjustable slope, so that it was possible to vary the Frovpe number between the limits $0.3<\dot{F}<2.5$. The width of the channel was $10.45 \mathrm{~cm}$, the throat width $5.20 \mathrm{~cm}$. The anglés were measured di-

(*) 10 of the 13 measurements were carried out by Mr, UfFe B. HaNSEN. 
TABLE II

\begin{tabular}{|c|c|c|c|c|}
\hline $\begin{array}{c}\text { Exp. } \\
N^{\circ}\end{array}$ & $1 / \mathrm{F}$ & $2 \pi y_{m} / b$ & $\begin{array}{l}\sin \theta \\
\text { meas. }\end{array}$ & $\begin{array}{l}\sin \theta \\
\text { theor. }\end{array}$ \\
\hline $14 a$ & ab. 0.40 & 3.5 & 0.22 & 0.21 \\
\hline b & ab. 0.53 & 4.2 & 0.27 & 0.26 \\
\hline$c$ & 0.657 & 4.9 & 0.32 & 0.29 \\
\hline$d$ & 0.785 & 5.1 & 0.38 & 0.33 \\
\hline $\mathrm{c}$ & 1.00 & 5.9 & 0.44 & 0.40 \\
\hline $\mathrm{f}$ & 1.25 & 6.9 & 0.48 & 0.48 \\
\hline $\mathrm{g}$ & 1.32 & 7.2 & 0.50 & 0.47 \\
\hline $\mathrm{h}$ & 1.65 & 8.3 & 0.55 & 0.53 \\
\hline $\mathrm{i}$ & 2.11 & 9.8 & 0.63 & 0.61 \\
\hline $\mathrm{j}$ & 2.47 & 10.8 & 0.66 & 0.66 \\
\hline k & 2.85 & 11.9 & 0.73 & 0.70 \\
\hline 1 & 3.28 & 13.1 & 0.76 & 0.74 \\
\hline $15 \mathrm{~b}$ & ab. 0.36 & 2.3 & 0.26 & 0.23 \\
\hline $\mathrm{c}$ & 0.421 & 2.55 & 0.31 & 0.26 \\
\hline d & 0.546 & 3.0 & 0.35 & 0.31 \\
\hline c & 0.704 & 3.6 & 0.40 & 0.37 \\
\hline f & 0.851 & 4.1 & 0.43 & 0.41 \\
\hline$g$ & 1.10 & 4.8 & 0.45 & 0.47 \\
\hline $\mathrm{h}$ & 1.27 & 5.3 & 0.54 & 0.52 \\
\hline $\mathrm{i}$ & 1.52 & 6.0 & 0.57 & 0.57 \\
\hline$j$ & 1.98 & 7.1 & 0.68 & 0.66 \\
\hline $\mathrm{k}$ & 2.59 & 8.5 & 0.74 & 0.73 \\
\hline 16 a & 1.66 & 8.72 & 0.51 & 0.52 \\
\hline b) & 1.65 & 7.60 & 0.55 & 0.55 \\
\hline$c$ & 1.66 & 6.18 & 0.59 & 0.59 \\
\hline$d$ & 1.64 & 4.84 & 0.63 & 0.65 \\
\hline $\mathrm{e}$ & 1.66 & 3.50 & 0.71 & 0.73 \\
\hline $17 a$ & 0.655 & 4.85 & 0.26 & 0.28 \\
\hline $\mathrm{b}$ & 0.655 & 4.41 & 0.32 & 0.31 \\
\hline $\mathrm{c}$ & 0.654 & 3.97 & 0.34 & 0.32 \\
\hline$d$ & 0.653 & 3.60 & 0.33 & 0.33 \\
\hline e & 0.655 & 2.51 & 0.38 & 0.40 \\
\hline $\mathrm{f}$ & 0.656 & 1.96 & 0.43 & 0.44 \\
\hline $\mathrm{g}$ & 0.651 & 1.65 & 0.46 & 0.46 \\
\hline $\mathrm{h}$ & $0.660^{\circ}$ & 1.29 & 0.53 & 0.51 \\
\hline
\end{tabular}

rectly with a protractor, the depth with a pointgauge (estimate $1 / 10 \mathrm{~mm}$ ), and the discharge with a Thomson weir. The results appear from Table II.

For $F<1$ (subcritical flow), the water surface was covered by a close wave pattern, consisting of waves of very small amplitudes.

The above mentioned Venturi flume experiments and experiment $14 e$ all corresponding to $\mathrm{F}=1$, experiments $16 a-e$ and $14 h$, corresponding to $1 / \mathrm{F}=1.65$, and experiments $17 a-h$ and $14 c$, corresponding to $1 / \mathrm{F}=0.655$, are represented graphically in Fig. 4, where $\sin 0=f\left(2 \pi y_{m} / b\right)$

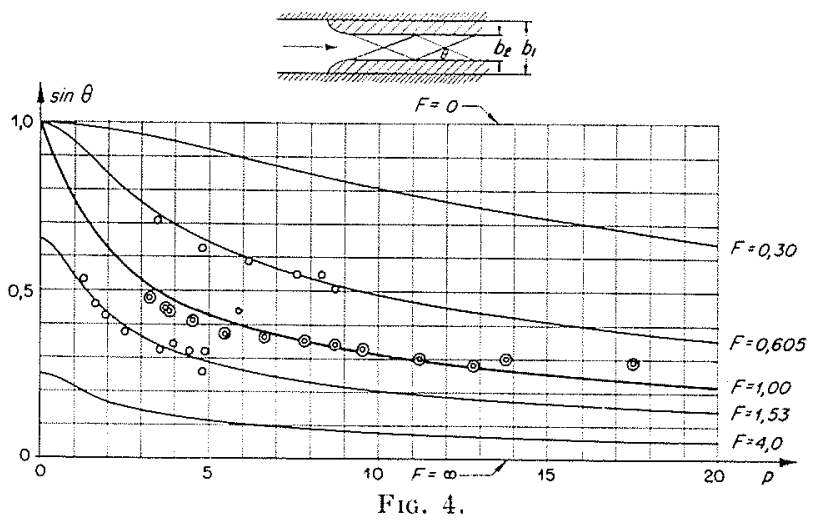

with parameter $\mathbf{F}$. The agreement is satisfactory; for the Venturi flume experiments, however, only if the quality of the measurements, the great slope of the water surface and the approximation $F=1$ are taken into consideration.

All the results of the Venturi flume experi-

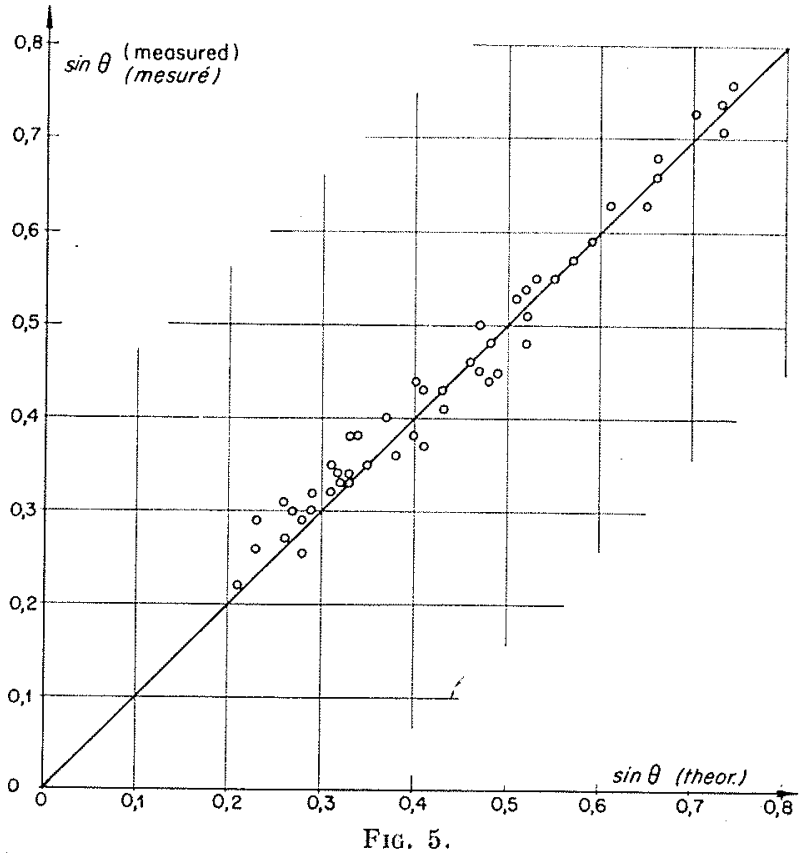


ments and the experiments 14, 15, 16, and 17 are represented graphically in Fig. 5 as a plot of $\sin \theta$ (measured) against $\sin \theta$ (theoretically). Thus, the points ought to lie on a straight line forming an angle of $45^{\circ}$ with the axes. The investigations cover most of the practical applications: $0.3<\mathbf{F}<2.5, \quad 0.2<y_{0} / b<3$, and $12^{\prime \prime}<\theta<50^{\circ}$.

The experiments mentioned in [1] p. $1348 \mathrm{fr}$. support further the theory in case of high-velocity flow, $\mathrm{F}=3$ and $\mathrm{F}=4$.

The agreement between the theoretical contour curves computed from (5): $y_{0}=y_{m}$ $+a \sin 2 \pi x / \lambda \cos 2 \pi z / b$ shown in Fig. 6 and the measured contours in Fig. $37 \mathrm{~b}$ in the above mentioned article is remarkable. That the eye will regard such a water surface as consisting of oblique waves appears elearly from Fig. 7, a photograph of a model made according to Fig. 6 laken in inclining incident light.

The wall and center-line profiles of the water surface indicated in $\lceil 1\rceil$ (Figs. $38 c$ and $46 a$ ) are approximately damped sinusoids. On the basis of the stated data we have computed $\lambda$ from Eq. (1) and Eq. (7) and compared these values with the measured values. The results, appearing from Table III, show that Eq. (7) is a very essential improvement.

Finally, only the determination of the amplitude a remains. Since this elevation produced

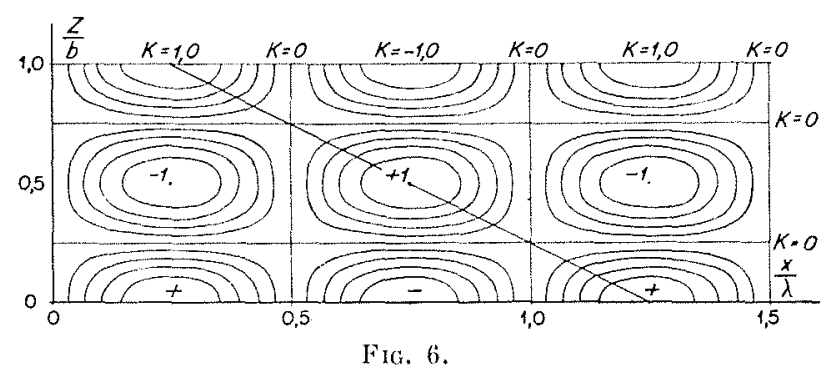

Conton curves (courbes de nivean)

$$
\begin{gathered}
\mathrm{K}=\frac{y_{0}-y_{m}}{a}=\sin \frac{3 \pi x}{\lambda} \cos \frac{2 \pi z}{b} \\
\text { Equidistance }=0.2
\end{gathered}
$$

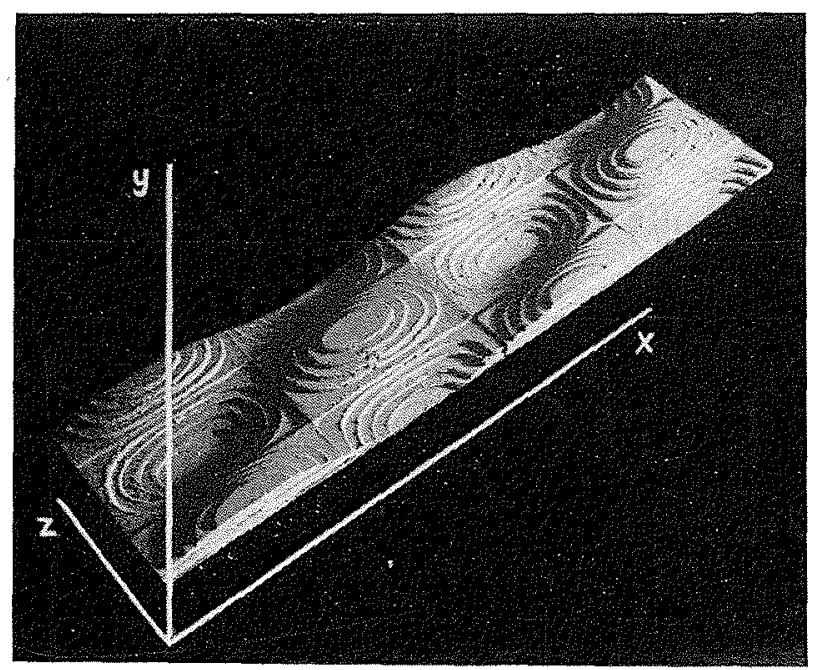

Fig. 7 ,

\begin{tabular}{|c|c|c|c|c|c|c|c|c|}
\hline \multicolumn{5}{|c|}{ Data taken from the paper [1] } & \multirow{3}{*}{$\frac{2 \pi h_{2}}{b_{2}}$} & \multicolumn{3}{|c|}{ Determination of $\lambda$} \\
\hline \multirow[t]{2}{*}{ Fig. $\mathrm{N}^{\circ}$} & \multirow[t]{2}{*}{ Section } & \multirow[t]{2}{*}{$\mathrm{F}$} & $h$ & $b$ & & $\begin{array}{c}\mathrm{Eq}_{\mathrm{q}} \cdot(1) \\
\sin v=\frac{1}{\mathrm{~F}_{2}}\end{array}$ & $\begin{array}{c}\text { Eq. }(7) \\
\sin v= \\
f\left(\frac{1}{F_{2}}, \frac{2 \pi h \cdot 2}{b_{2}}\right)\end{array}$ & Exper. \\
\hline & & & $\mathrm{ft}$ & $\mathrm{ft}$ & & $\mathrm{ft}$ & $\mathrm{ft}$ & $\mathrm{ft}^{\mathrm{t}} \mathrm{c}$ \\
\hline $37(\mathrm{~b}), 38(\mathrm{c})(\mathrm{d}) \ldots$ & 1 & 4.0 & 0.10 & 2.0 & & & & \\
\hline 46 (a) ${ }_{I I}, 49$. & 2 & 2.5 & 0.22 & 1.0 & 1.4 & 2.3 & 3.1 & 3.4 \\
\hline & 1 & 3.0 & 0.10 & 2.0 & & & & \\
\hline & 2 & 1.5 & 0.25 & 1.0 & 1.6 & 1.1 & 1.9) & 2.0 \\
\hline & 1 & 3.0 & 0.20 & 2.0 & & & & \\
\hline 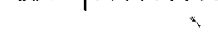 & 2 & 1.5 & 0.51 & 1.0 & 3.2 & 1.1 & 2.7 & 3.0 \\
\hline
\end{tabular}

TABLE III 
the necessary centripetal acceleration, it seems reasonable to assume that $a$ is proportional to $v^{2}$. Then the ratio $a / v^{2} / 2 g$ should essentially depend on the shape of the inlet (and the outlet), but for a given Venturi flume this ratio should be a constant for all discharges. The accuracy of the measurements does not justify a closer investigation, but the order of magnitude can be indicated for experiments 1-10, i.e., for $F=1$. Computing the ratio between the maximum amplitudes and the velocity head in the inlet, $v_{i}^{2} / 2 g$, we get :

TABLE IV

\begin{tabular}{|c|c|c|c|}
\hline Inlet & & $x=0 \mathrm{~cm}$ & $a_{i} \mid \frac{v_{i}^{2}}{2 g}=0.2 \overline{3}$ \\
\hline Parallel part & {$\left[\begin{array}{r}\text { Betw. } 1^{\prime} \text { and } \\
2^{\prime} \text { zero } \\
\text { Betw. 2' and } \\
3 \text { zero }\end{array}\right.$} & $\begin{array}{l}x=20-30 \mathrm{~cm} \\
x=40-50 \mathrm{~cm}\end{array}$ & $a_{n} \mid \frac{v_{i}^{2}}{2 g}=0.5$ \\
\hline Outlet & & $x=90-100 \mathrm{~cm}$ & $a_{\theta} \mid \frac{v_{i}^{2}}{2 g}=1.0$ \\
\hline
\end{tabular}

The mean error on this determination was $15-25 \%$.

The wave Pattern Caused by a Channel EXPANSION.

SUPERCRTTCAL Flow.

While experiments thus seem to indicate that the water surface after an S-shaped channel contraction is to a great extent dominated by the wave of the second order, conditions downstream a channel expansion are much more complicated. The experiments mentioned in this section have been carricd out to shed some light on this question.

In a $60 \mathrm{~cm}$ wide channel was built a $37 \mathrm{~cm}$ wide wooden channel, provided with a parabolic transition, $45 \mathrm{~cm}$ in length and forming an angle of $20^{\circ}$ with the channel walls (see photograph, Fig. 1). The bottom of the wooden channel was clevated $5 \mathrm{~cm}$ above the bottom of the larger channel. The discharge was determined to be $0.1003 \mathrm{~m}^{3} / \mathrm{s}$, measured with a THOMson weir, The water surface was surveyed with a pointgauge, measuring cross-sections $10 \mathrm{~cm}$ apart.

Some of the results are given in Fig. $8 a$. The mean depth increased slightly in the direction of flow, the average value over the surveyed part was determined to be $8.25 \mathrm{~cm}$.

Considering the results, we realize at once that a water surface of this kind cannot in a satisfactory way be in accordance with Er. (5). The periodicity is not quite regular and the profiles are much too irregular and crested to he represented by a single cosinusoid. Consequently, we may suppose that an expression of the form (8) will be more suitable. To verify this asssumption a harmonic analysis of all the surface profiles shown in Fig. $8 a$ has been carricd out. The Fovrien coefficients obtained by this procedure are plotted in Fig. $8 b$ as functions of the abscissa $x$. The exnression (8) will hold only if the curves obtained in this wav are
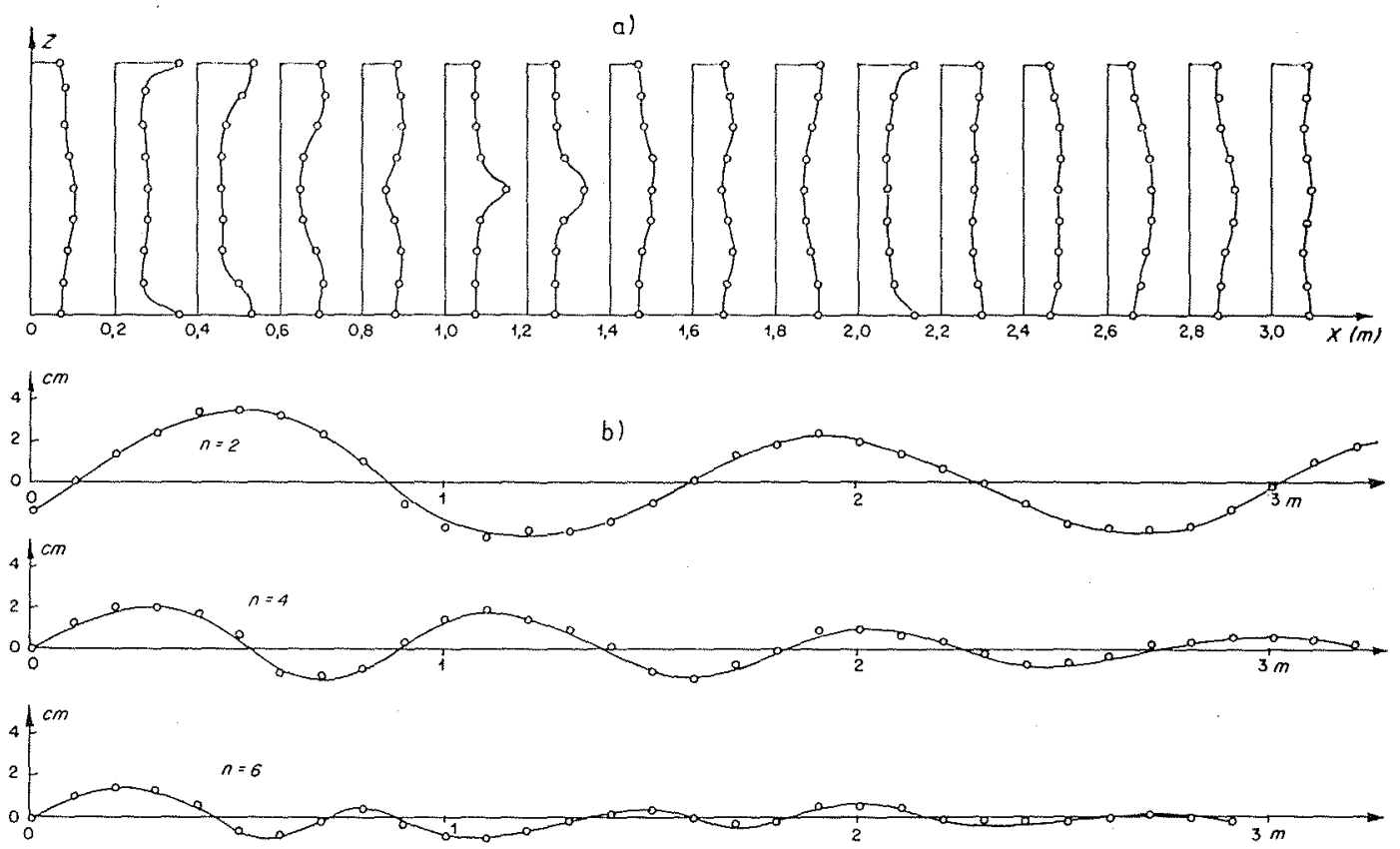

Fig. 8. 


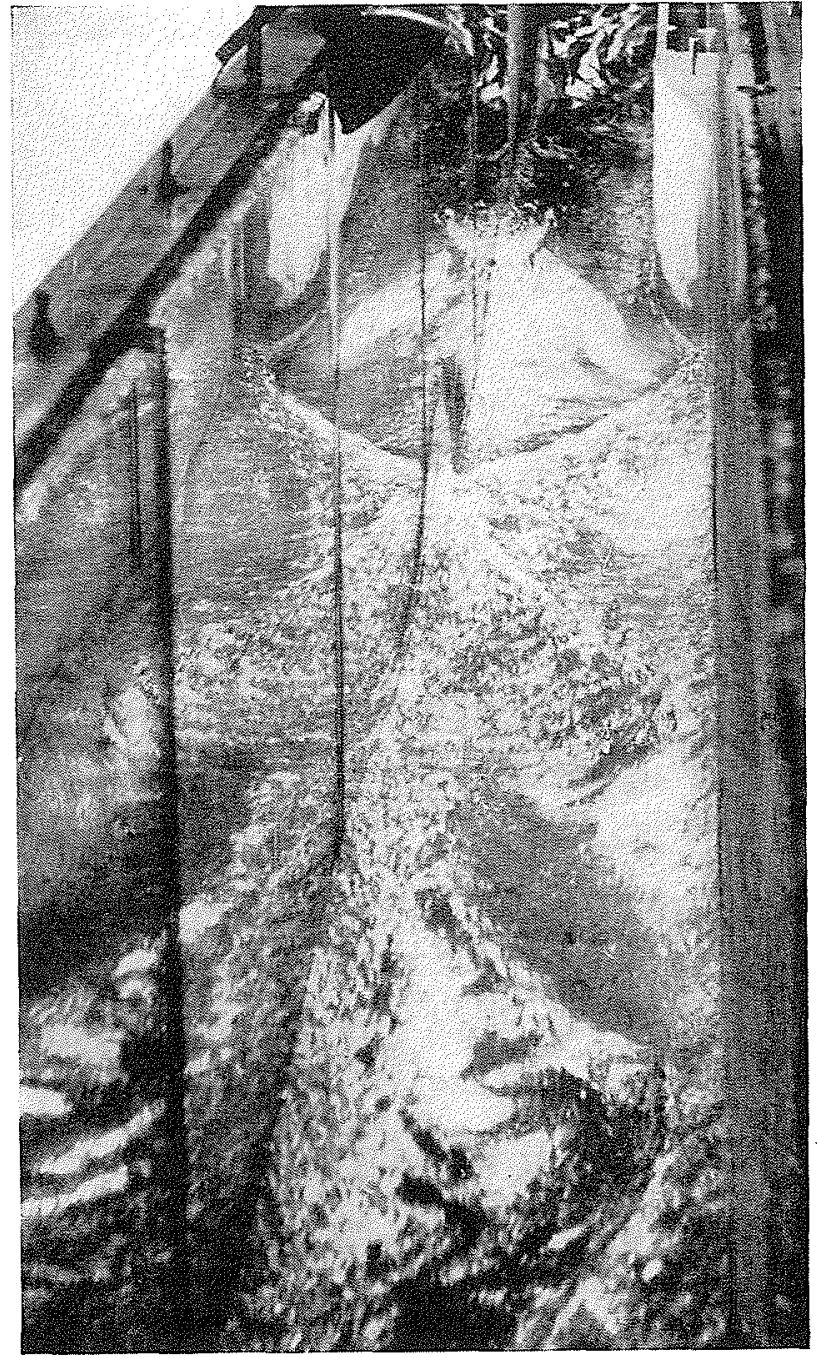

FIG. 9.

the sinusoids $a_{n} \cdot \sin 2 \pi x / \lambda_{n}$. It appears from Fig. $8 b$ that the curves really are very nearly sinusoidal, apart from a certain damping, pos- sibly due to the neglected friction. Further, it may be noticed that the amplitudes are fairly great, which maybe tends to enlarge the deviation of the curves from the theoretical sinusoids.

The waves of the 6 th and higher orders are very much damped and the influence of these waves has almost completely disappeared some $2.5 \mathrm{~m}$ from the expansion.

The wave of the second order gets nearest to the sinusoid. The first half-period amplitude is, indeed, somewhat greater than the succeeding three, which may be due to real damping but also may be explained by the lesser accuracy of the measurements caused by the extreme variations of the surface.

The periodicity of the waves of second and fourth orders is quite clear, and the wave length can be established with good accuracy al $\lambda_{2}=1.44 \mathrm{~m}$ and $\lambda_{4}=0.90 \mathrm{~m}$ respectively.

From the given data we get the Frovde number $\mathrm{F}=2.25$ and $2 \pi y_{m} / b=0.864$. Thus the theoretical values of the wave lengths become $\lambda_{2}=1.40 \mathrm{~m}$ and $\lambda_{4}=0.89 \mathrm{~m}$, in good agreement with the experimental values. The corresponding wave angles $\theta$ are $23^{\prime \prime} .1$ and $18^{\circ} .7$ respec tively, while $\mathrm{Eq}$. (1) gives $0=26^{\circ} .4$.

The wave of the 6th order is less regular, which can probably be explained by the fact that the accuracy of the curves must necessarily decrease when the order is increased. The period is however, in good agreement with the theoretical value $(0.71 \mathrm{~m})$, except in the interval from $x==1.40 \mathrm{~m}$ to $x=1.80 \mathrm{~m}$. This deviation is maybe a consequence of the formation of foam and droplets in the preceding sections (about $x=1,2 \mathrm{~m}$ ).

A similar experiment has been carried out with a one-sided S-chaped channel expansion (photo, Fig. 9). From a theoretical point of view there would be no fundamental difference

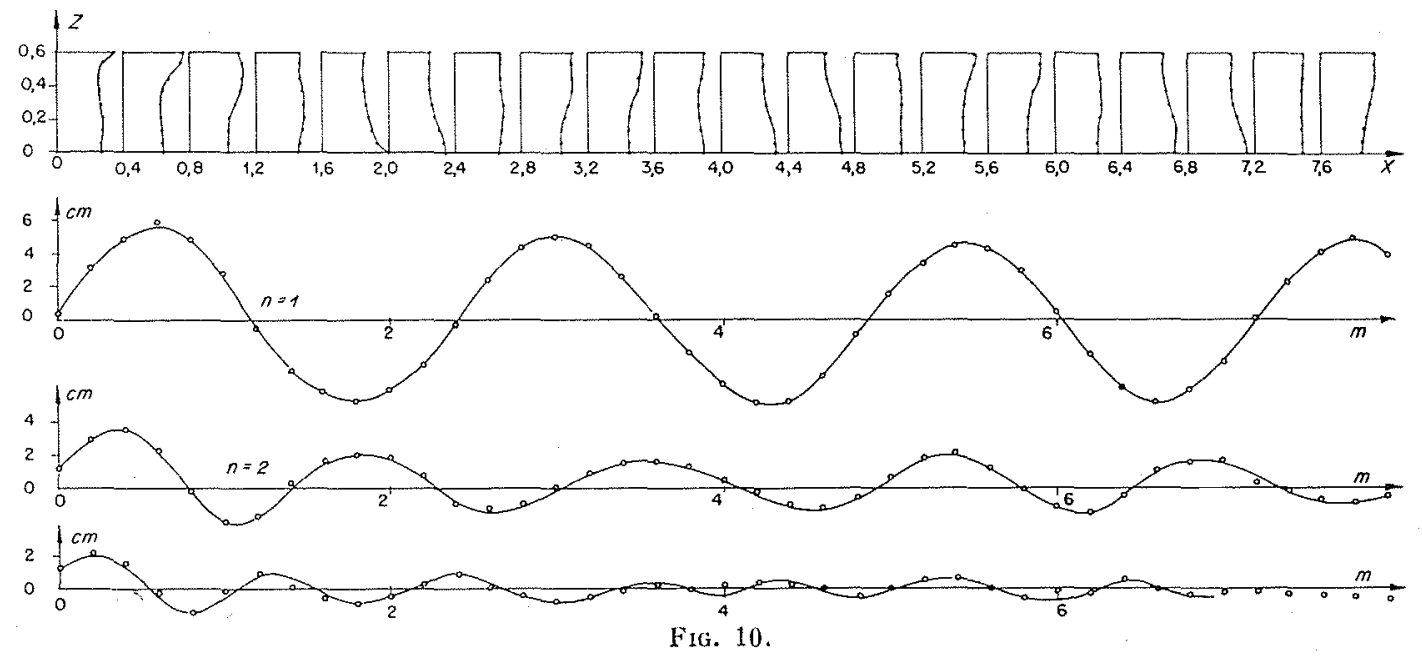


between the one-sided and the symmetrical expansion, because the flow in the one-sided expanded channel can be interpreted as onehalf of a symmetrical flow in a channel of the double width. This is illustrated in Fig. 9, where the reflection in the glass-wall produces the illusion of a symmetrical flow.

Results of the surveying and the harmonic analysis of the water surface are presented in Fig. 10. The main difference between these results and the preceeding ones is that there is no sign of any appreciable damping, if the first half-period is neglected. Thus the curves found may-within the limits of the experimental accuracy-be replaced with sinusoids corresponding to the wave lengths $\lambda_{1}=2.4 \mathrm{~m}$, $\lambda_{2}=1.65 \mathrm{~m}$ and $\lambda_{3}=1.01 \mathrm{~m}$.

The discharge was measured as $0.448 \mathrm{~m}^{3} / \mathrm{s}$, the mean water depth (increasing slightly in the direction of the flow) as $0.28 \mathrm{~m}$ on an average. From this we get the Froune number $\mathrm{F}=1.608$ and $\pi y_{m} / b=1.466$. Corresponding to E(f. (7) the wave lengths would then bo $\lambda_{1}=2.28 \mathrm{~m}, \lambda_{2}=1.60 \mathrm{~m}$ and $\lambda_{3}=0.97 \mathrm{~m}$, in good agreement with the experimental values.

While this experiment seems to be a more convincing verification of the theory than the previous one, this is in accordance with the fact that the difference between the fundamental assumptions and their experimental representalion is much smaller.

\section{Conclusion And Discussion of the RESUlts.}

The primary conclusion from the preceding results is that the simple $\mathrm{E}_{\mathrm{q}}$ (1) is an extreme case corresponding to high-velocity flow in broad rectangular channels. Further, it has been proved that the generalization (7) developed in the present paper is in good agreement with new and older experiments covering quile considerable variations of the Froude number $F$ and the parameter $y_{m} / b$.

It has been demonstrated theoretically that the water surface can be described by an expression of the form (8), i.e., by adding an infinite number of waves of different order's and different wave lengths. This explains the lack of regular periodicity and the curvature of the wave fronts (see Fig. 9). The experimental results are in good agreement with the theory, apart from a more or less pronounced damping of the waves, not included in the theory.

The fundamental assumptions underlying the theory thus seem to be fairly satisfactory. The effect of the friction has already been mentioned.

The surface tension will be of significance only in very small channels, and its effect has not been investigated, although it would cause no serious mathematical difficulties.

It would be of greater interest to carry out a second-order approximation, but this would be so complieated that it would probably be of little practical value.

The following still unsolved problems may be mentioned :

1) Prediction of the magnitude of the amplitudes $a_{n}$ when the geometry of the lateral boundaries and the discharge are given.

2) The position of waves of different orders in relation to each other.

3) Computation of the damping.

4) The effect of air entrainment.

\section{ACKNO WLEGD MENT.}

The authors are indebted to professor A.E. BreTrTse, director of the Hydraulic Laboratory, for his permission to carry out the experiments and for his interest in the present investigalions, and to professor, Dr. Richard Preterser, director of the Laboratory of Applied Mathematies, for having placed the harmonic analyser at their disposal.

\section{REFERENCES :}

[1] Proceedings of the American Society of Civil Engineers, vol. 75, 1949, p. 1290 ff.

[2] A.T. IPPEN : Transitions for Supereritical Flow. Chapter VIII D in Engineering Hydraulies, 1949, edited by Hunter Rouse. 


\title{
Écoulement permanent
}

\section{dans les canaux convergents et divergents}

\section{(Considérations sur la forme de la surface libre)}

\author{
PAR FRAN ENGRILUND ET JoHS. MUNCH-PETERSEN \\ LABORATOHE D'HYDRALLIOLE,

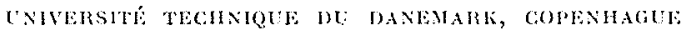

English text, p. 464.

\begin{abstract}
Les hypotheses: canal rectangulaire horizontal, fluide incompressible, ecoulement it potentiel, théorie linéaire, on néglige la tension superficielle et l'entrainement d'air. Etablissement de l'équation générale de la surface libre a partir de l'équation de Laplace. - Discussion des diverses expressions de langle de Mach en fonction du nombre de Froude et de la profondeur relative. - Application, abec controle expérimental, au cas dun canal convergent stgmétrique, puis à celui d'un canal divergent, en écoulement suprecrilique.
\end{abstract}

$$
\begin{aligned}
& \text { NOTATIONS } \\
& \%=\text { potentiel des vitesses. } \\
& \bar{\nu}=\text { vecteur vitesse. } \\
& v=\text { grandeur de la vitesse. } \\
& b_{x}, b_{y}, b_{z}=\text { composantes de la vitesse. } \\
& v_{m}=\text { vitesse moyenne d'une section. } \\
& y_{0}=\text { cote de la surface libre. } \\
& y_{m}=\text { profondeur moyenne. } \\
& y_{c}=\text { profondeur critique. } \\
& g \text { = accélération de la pesanteur } \\
& \left(9,82 \mathrm{~m} / \mathrm{s}^{2}\right) \text {. } \\
& \mathrm{F}=\frac{v_{m i}}{\sqrt{g y_{m}}}=\text { nombre de Frouns. }
\end{aligned}
$$

$H=$ charge spécifique.

$b=$ largeur du canal.

$n=$ nombre entier.

$\lambda_{n}=$ longueurs d'onde.

$a_{n}=$ amplitudes.

0 = angle des ondes avec les parois du canal.

$\nabla=$ opérateur Nabla.

La surface libre d'un écoulement à grande vitesse est souvent quelque pey irrégulière et ondulée; c'est là un fait bien connu grâce aux recherches hydrauliques de ces dernières décades. Lorsque la section varie ou si le canal est courbe, il se forme un réseau d'ondes stationnaires dont la fi- 
gure 1 (") montre un exemple; dans ce dernier cas, c'est l'élargissement d'un canal qui provoque ces ondes.

On a démontré qu'un écoulement à grande vitesse (qui correspond à des valeurs relativement grandes du nombre de Froude $\mathrm{F}=\frac{v_{m}}{\sqrt{g y_{m}}}$ ) est analogue a l'écoulement supersonique des gaz; cette analogie a été souvent signalée et utilisée. A.I. IPPEx a donné des indications détaillées et complètes sur ces recherches dans [1] et [2] où l'on trouvera d'autres références.

Pour caractériser les ondes, nous introduirons l'angle 0 qu'elles forment avec les parois latérales du canal. On sait que, pour de faibles amplitudes, on peut calculer o par la formule :

$$
\sin \theta=\frac{1}{\mathrm{~F}}=\frac{\sqrt{g} y_{m}}{v_{m}}
$$

Cette expression est tout a fait analogue à celle que l'on emploie pour représenter l'angle de Macu dans l'écoulement supersoniciue. Elle peut être généréalisée au cas des ondes d'amplitude finie. Tous ces résultats ont été vérifiés par un grand nombre d'expériences.

S'il ne fait aucun doute que l'expression (1) est valable dans la plupart des cas d'écoulements à grande vitesse, plusieurs observations semblent cependant indifuuer qu'il n'en est plus de même lorsque le nombre de Froude se rapproche de l'unité. En somme, on peut dire que (1) n'a de signification que pour $F>1$, c'est-à-dire en écoulement supracritique; tontefois des expériences (que nous relaterons plus loin) effectuées dans un canal Venturi ont montré qu'il peut exister des ondes de même nature au voisinage de la profondeur critique, c'està-dire pour $F=1$, et même pour des nombres de Froune inférieurs à 1. Enfin l'expression (1) n'est pas parfaite même pour les écoulements à grande vitesse, sauf dans le cas où la largeur du canal est grande par rapport à la profondeur $y_{m}$.

Il s'avère donc nécessaire de traiter le problème plus généralement et le présent article n'a d'autre but que de chercher à établir une théorie plus générale, capable d'englober tous les résultats observés.

\section{THÉORIE FONDAMENTALE.}

Nous ferons les hypothèses suivantes, sur la validité desquelles nous reviendrons :

1. L'éconlement a lieu dans un canal horizontal de section rectangulaire. On utilise un système de coordonnées cartésiennes dont l'axe $x$ est dans Ie sens longitudinal du canal, l'axe $y$ vertical ascendant et l'axe $z$ perpendiculaire aux parois du canal (voir fig. 7).

2" L'écoulement est à potentiel de vitesse dans un fluide incompressible; on néglige donc les frottements, ce que nous justifierons par la suite.

(*) Pour les figures se reporter au texte anglais p. 464
Si on représente le potentiel des vitesses par o, on a :

$$
\begin{aligned}
\bar{\nu} & =-\nabla \varphi \\
\text { ou } v_{u}=-\frac{\partial \varphi}{\partial x}, \quad v_{y} & =-\frac{\partial \varphi}{\partial y}, \quad v_{z}=-\frac{\partial \varphi}{\partial z}
\end{aligned}
$$

L'équation de continuité exprimant l'incompressibilité du fluide s'écrit :

$$
\nabla \cdot \bar{v}=\frac{\partial v_{x}}{\partial x}+\frac{\partial v_{y}}{\partial y}+\frac{\partial v_{z}}{\partial z}=0
$$

En conjuguant ces équations, on obtient l'écuation de LAPLACE :

$$
\frac{\partial^{2} \varphi}{\partial x^{2}}+\frac{\partial^{2} \varphi}{\partial y^{2}}+\frac{\partial^{2} \varphi}{\partial z^{2}}=0
$$

3" Les écarts relatifs par rapport à la profondeur moyenne sont assez petits pour qu'on puisse négliger les puissances d'ordre 2 ou supérieur. Il s'agit done d'une théorie linéaire. Cependant les expériences que nous relaterons semblent indiquer que l'on peut admettre des écarts déjà appréciables.

$4^{\circ}$ On néglige l'influence de la tension superfcielle et de l'entraînement d'air possible.

Considérons d'abord un simple éconlement symétrique, e'est-à-dire un écoulement symétrique par rapport au plan vertical $z=(1 / 2) \mathrm{b}$. Une solution simple de l'écquation (3) est :

$\vartheta=-v_{m} x-c \cdot \cosh \left(2 \pi y \sqrt{-\frac{1}{b^{2}}+\frac{1}{\lambda^{2}}}\right) \cdot \cos \frac{2 \pi x}{\lambda} \cdot \cos \frac{2 \pi z}{b}$

où $v_{m}$ est la vitesse moyenne de l'écoulement, $b$ la largeur de canal, $\lambda$ la longueur d'onde de l'onde stationnaire et $c$ une constante arbitraire. Nous allons démontrer que (4) satisfait aux conditions limites.

La première condition a remplir est que la vitesse le long des parois du canal ne doit pas avoir de composante perpendiculaire à ces dernières, c'est-à-dire que :

$$
\begin{aligned}
& v_{z}=-\frac{\partial \varphi}{\partial z}=0 \text { pour } \quad z=0 \mathrm{et} z=b \\
& v_{y}=-\frac{\partial \varphi}{\partial y}=0 \quad \text { pour } \quad y=0
\end{aligned}
$$

On voit que (4) satisfait automatiquement à ces conditions. Pour pouvoir exprimer une troisième condition, il faut d'abord établir l'équation de la surface libre. Dans ce but, développons les équations :

$$
v_{x}=-\frac{\partial \varphi}{\partial x} \rightleftharpoons v_{m}+
$$

c. $\frac{2 \pi}{\lambda} \cdot \cosh \left(2 \pi y \sqrt{\left.\frac{1}{b^{-}}+\frac{1}{\lambda^{2}}\right)} \cdot \sin \frac{2 \pi x}{\lambda} \cdot \cos \frac{2 \pi z}{b}\right.$ 
$v_{x^{2}}^{2} \cong v^{2}=v_{m}^{2}+2 v_{m} \cdot c \cdot \frac{2 \pi}{\lambda}$

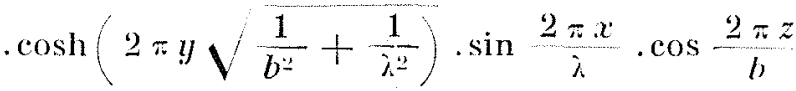

où l'on a négligé les puissances de c d'ordre 2 ou supérieur.

Soit $y_{0}$ la cote d'un point de la surface libre et $v_{0}$ la vitesse en ce point. En désignant par $H$ la charge spécifique, on a :

$$
\mathrm{H}=y_{0}+\frac{v_{0}^{2}}{2 g}
$$

En remplaçant $y^{2}$ par sa valeur, on obtient :

$y_{10}=\left(\mathrm{H}-\frac{v_{m}^{2}}{2 q}\right)-2 \pi c \cdot \frac{v_{m}}{g \lambda}$

$\cosh \left(2 \pi y_{m} \sqrt{\left.\frac{1}{b^{2}}+\frac{1}{\lambda^{2}}\right)} \cdot \sin \frac{2 \pi x}{\lambda} \cdot \cos \frac{2 \pi z}{b}\right.$

soit :

$$
y_{0}=y_{m}+a \cdot \sin \frac{2 \pi x}{\lambda} \cos \frac{2 \pi z}{b},
$$

où $y_{m}$ représente la profondeur moyenne et a l'amplitude.

La troisième condition limite est que, en chaque point de la surface libre, le vecteur vitesse $\bar{v}=\left(v_{i c}, v_{y}, v_{\varepsilon}\right)$ doit être tangent à la surface libre, ou, ce qui revient au même, être perpendiculaire à la normale de la surface libre en ce point. Le plan tangent en un point de la surface libre peut être défini par deux vecteurs linéairement indépendants $\overline{F_{1}}$ et $\overline{F_{2}}$, tous deux tangents $\dot{a}$ la surface libre. Ces deux vecteurs sont par exemple :

$$
\overline{\mathrm{F}}_{1}=\left(1, \frac{\partial y_{0}}{\partial \boldsymbol{x}}, 0\right) \text { et } \overline{\mathrm{F}}_{2}=\left(0, \frac{\partial y_{0}}{\partial z}, 1\right)
$$

Le produit vectoriel de ces deux vecteurs est un vecteur $\bar{n}$ dirigé suivant la normale :

$$
n=\overline{\mathbf{F}}_{1} \times \overline{\mathbf{F}}_{2}=\left\{\frac{\partial y_{0}}{\partial x}, \cdots 1, \frac{\partial y_{0}}{\partial z}\right\}
$$

On pent maintenant exprimer la troisième condition en écrivant que le produit scalaire de $\vec{v}$ et $\vec{n}$ est nul.

$$
\bar{v} \cdot \bar{n}=0=\frac{\partial y_{0}}{\partial x} \cdot v_{x}-v_{\sharp \prime}+\frac{\partial y_{0}}{\partial z} \cdot v_{z}
$$

Le dernier terme de cette équation étant du second ordre en $a$ peut par conséquent être négligé. La condition devient alors :

$$
\frac{\partial y_{0}}{\partial x} \cdot v_{x}-v_{y}=0
$$

pour $y=y_{0}$. En tenant compte des expressions (2)
(4) (5), on trouve que la troisième condition limite est satisfaite si :

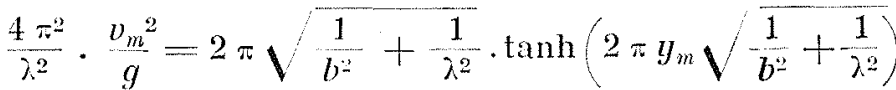

On remarque encore que l'équation (5) de la surface libre peut s'écrire:

$y_{0}=y_{m}+\frac{1}{2} a\left[\sin 2 \pi\left(\frac{x}{\lambda}+\frac{z}{b}\right)+\sin 2 \pi\left(\frac{x}{\lambda}-\frac{z}{b}\right)\right]$

dont les "caractéristiques" sont :

$$
\frac{x}{\lambda}+\frac{z}{b}=\text { const. et } \frac{x}{\lambda}-\frac{z}{b}=\text { const. }
$$

L'angle 0 de ces lignes d'onde et des parois du canal est par conséquent défini par:

$$
\operatorname{tang} \theta=\frac{b}{\lambda}
$$

ou encore :

$$
\sqrt{\frac{1}{b^{2}}+\frac{1}{\lambda^{2}}}=\frac{1}{b \cos 0}
$$

En portant cette expression dans l'équation (6), il vient:

$$
\sin \theta=\frac{\sqrt{g y_{m}}}{v_{n}} \cdot \sqrt{\frac{\operatorname{lanh}\left(\frac{2 \pi y_{m}}{b} \cos \theta\right.}{\frac{2 \pi y_{m}}{b} \cdot \frac{1}{\cos \theta}}}(7)
$$

où $\frac{\sqrt{g y_{m}}}{v_{m}}$ est egal à $1 / \mathrm{F}$. (7) est l'équation générale cherchée dont (1) est un cas particulier.

Pour des valeurs assez petites du parametre $p=2 \pi y_{m} / b$, on peut érire de facon approchée :

$$
\tanh \left[\frac{2 \pi y_{m}}{b}, \frac{1}{\cos \theta}\right] \cong \frac{2 \pi y_{m}}{b} \cdot \frac{1}{\cos \theta}
$$

de sorte que l'équation (7) est pratiquement identique à (1).

Pour des valeurs assez grandes de $2 \pi y_{m} / b$, on a :

$$
\tanh \left(\frac{2 \pi y_{m}}{b} \cdot \frac{1}{\cos \theta}\right) \cong 1
$$

En tenant compte de cette équivalence et de la relation $b \cos \theta=\lambda \sin \theta$, (7) se réduit à :

$$
\sin \theta=\left(\sqrt{\frac{g \lambda}{2 \pi}} \cdot \frac{1}{v_{m}}\right)^{2}
$$

Il est intéressant de noter que $\sqrt{\frac{g \lambda}{2 \pi}}$ est la célérité d'une onde en eau profonde, de même que $\sqrt{g y_{m}}$ est l'expression classique de la célérité d'ondes en eau peu profonde. 
Lorsqu'on connaît $\mathrm{F}$ et le paramètre $p=2 \pi y_{m} / b$, l'équation (7) permet de calculer $\theta$ par approximations successives, mais il est plus commode d'utiliser le graphique de la figure 2 , avec une précision bien suffisante en général.

I a solution que fournissent (4), (5) et (7) n'est cependant pas la seule à remplir les conditions limites. Si dans (4) on met le coefficient $\cos (4 \pi z / b)$ au lieu de $\cos (2 \pi z / b)$, les mêmes conditions limites sont encore satisfaites. Pour le voir, il n'est pas nécessaire de refaire les calculs en détails; il suffit de remplacer $b$ par $b / 2$ dans toutes les équations. La nouvelle solution correspond à une longueur l'onde différente et un angle 0 différent que l'on détermine sur le graphique de la figure 2 en prenant pour $p$ la valeur $4 \pi y_{m} / b$ au lieu de $2 \pi y_{m} / b$ précédemment.

On peut done obtenir une infinite de solutions en utilisant dans (5) le facteur $\cos n \pi z / b$. L'écoulement symétrique correspond aux valeurs paires de $n$. On déterminera la longueur d'onde correspondante au moyen du graphique de la figure 2, en prenant pour $p$ la valeur $n \pi y_{m} / b$. Pour distinguer ces différentes solutions, nous parlerons d' "ondes (lu $n^{\circ}$ ordre " et nous désignerons par $\lambda_{n}$ et $\theta_{n}$ les longueurs d'onde et les angles correspondants.

Il est important de remarquer que, dans les limites d'une théorie de premier ordre (c'est-it-dire lorsqu'on peut négliger les puissances d'ordre supérieur (ies amplitudes), on peut obtenir de nouvelles solutions en additionnant les solutions particulières. II est, par conséquent, possible de généraliser l'équation (5) et l'expression générale de la cote de la surface libre se présente comme une série de FouRIER.

$$
y_{0}=y_{m}+\sum_{n} a_{n} \cdot \sin \frac{2 \pi}{\lambda_{n}}\left(x_{n}+\delta_{n}\right) \cdot \cos \frac{n \pi z}{b}
$$

\section{CAS D'UN CANAL CONVERGENT SYMÉTRIQUE}

(Canal Venturi, etc.)

L'équation (8) montre que l'on peut considérer la surface libre comme résultant de la superposition d'une infinité d'ondes stationnaires dont l'angle $\theta$ avec les parois latérales diminue lorsque $n$ croit.

Du fait de la symétrie, seules les valeurs paires de $n$ convienment, mais il est impossible de prévoir dans le détail la forme de la surface libre si on ne connaît pas au préalable les différentes amplitudes $a_{2}, a_{n}, \ldots a_{n}$. Toutefois, dans un canal convergent, les amplitudes diminuent en général très rapidement lorsque $n$ croit, de sorte que l'angle 0 de l'onde résultante ne diffère pas beaucoup de la valeur obtenue pour $n=2$. Lorsque la contraction est importante (dans le cas étudié le rapport de contraction est environ 2:1), les expériences montrent que même pour une transition très régulière il $y$ a une perturbation appréciable qui, du point de vue pratique, peut être considérée comme une onde pure du deuxième ordre.

La figure 3 représente les profils de la surface libre dans un canal Venturi, profils relevés à la pointe de mesure tous les $\mathrm{cm}$ avec une précision de $1 \mathrm{~mm}$.
L'écoulement est d'abord parallèle dans le troncon d'amenée, puis les lignes de courant s'infléchissent vers le plan de symétrie (fig. $3 a$, au voisinage de $x=0$ ). Il faut donc qu'il y ait surpression aux parois, ce qui se traduit par une surélévation du niveau de leau aux bords et un abaissement au milieu du canal. Au voisinage de $x=10 \mathrm{~cm}$, les lignes de courant présentent un point d'inflexion (repéré par le premier point zéro), après lequel elles s'incurvent dans l'autre sens; le profil transversal de la surface libre présente alors son maximum au milieu du canal. A l'extrémité du rétrécissement, on retrouve les mêmes conditions. On constate (fig. $3 b$ ) que transversalement les profils de la surface libre ont une forme sinusoüdale. Dans le sens longitudinal, les oscillations de la surface affectent approximativement une forme sinusoïdale aussi bien le long des parois qu'au centre du canal (fig. $3 c$ ). Il apparaît done vraisemblable qu'on puisse déterminer la surface libre à partir du graphique établi en fonction de $1 / F$ et $p=2 \pi y_{m} / b$. Sur le profil longitudinal de la surface libre on a pris pour $\lambda$ la distance séparant le premier et le troisième point zéro; on estime que la valeur correspondante de $y_{m}$ est $y_{c}$ et par suite $F=1$. Les mesures montrent qu'au voisinage du deuxième point zéro, on peut écrire : $y_{m}=y_{c}$. Une analyse plus précise du profil de la surface libre montre que, compte tenu de la pente et de la courbure de la surface libre dans le plan vertical, la change spécificue est minimum (profondeur correspondante $y_{m}=y_{c}$ ) dans la partie parallèle de la section contractée et non à l'extrémité de l'étranglement; on constate de plus que $y_{c}$ est encore égal à $\% / 3 \mathrm{H}$, puisque la surface libre moyenne présente un point d'inflexion pour $y_{m}=y_{c}$; ainsi l'influence de la courbure n'est pas capitale.

La théorie précédente a été vérifiée au moyen d'une série d'expériences (") réalisées dans un canal Venturi à fond horizontal (fig. 3). Les résultats en sont indiqués dans le tableau I (ci-après).

On voit que le premier point zéro s'établit toujours au voisinage de $x=10 \mathrm{~cm}$, c'est-à-dire au $\mathrm{mi}$ lieu du rétrécissement, et que les deuxième et troisième points zéro se déplacent un peu vers l'aval lorsque le débit augmente, mais pas plus loin que ne le permettent les considérations ci-dessus sur la position des points zéro et l'origine des ondes. En outre, il faut admettre que la position et la courbure de la.surface libre sont étroitement liées à la position de $y_{c}$ et des points zéro ainsi qu'à la relation entre $\mathrm{F}, 2 \pi y_{m} / b$ et $\lambda$.

Une autre série d'expériences a été réalisée dans un canal plus petit à pente réglable, de facon à pouvoir faire varier le nombre de Frovde dans les limites : $0,3<F<2,5$. La largeur du canal etait de $10,45 \mathrm{~cm}$ et celle de la section contractée de $5,20 \mathrm{~cm}$. On a mesuré les angles directement avec un rapporteur, les profondeurs au moyen d'une pointe de mesure (précision $1 / 10 \mathrm{~mm}$ ) et les débits par un déversoir Thomson. Les résultats sont rapportés dans le tableau II.

Pour $F<1$ (écoulement infracritique), la surface de l'eau était couverte d'un reseau serré d'ondes de très petites amplitudes.

(*) 10 des 13 mesures ont été effectuées par M. Uffe B. Hansen. 
TABLEAU I

\begin{tabular}{|c|c|c|c|c|c|c|c|}
\hline क्षिठ & \multicolumn{3}{|c|}{ Point zéro $(x$ en $\mathrm{cm})$} &  & $2 \pi y_{c} / b$ & 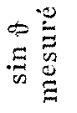 & 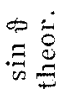 \\
\hline 1 & 12,1 & 30,0 & 47,1 & 35,0 & 3,26 & 0,48 & 0,52 \\
\hline 2 & $11, \bar{a}$ & 32,9 & 48,3 & ab. 37,0 & 3,71 & 0,46 & 0,49 \\
\hline 3 & 12,1 & 32,2 & 51,0 & 38,9 & 3,82 & 0,44 & 0,48 \\
\hline 4 & 12,0 & 32,6 & 54,4 & 42,4 & 4,55 & 0,41 & 0,43 \\
\hline 5 & 12,2 & 32,2 & 60,4 & 48,2 & 5,50 & 0,37 & 0,41 \\
\hline 6 & 10,6 & 35,0 & 60,0 & 49,4 & 6,67 & 0,36 & 0,38 \\
\hline 7 & 10,0 & 32,3 & 61,5 & 51,5 & 7,87 & 0,35 & 0,35 \\
\hline 8 & 11,3 & 38,5 & 63,9 & 52,6 & 8,75 & 0,34 & 0,33 \\
\hline 9 & 11,1 & 38,2 & 65,2 & 54,1 & 9,53 & 0,33 & 0,32 \\
\hline 10 & 8,5 & 37,8 & 68,8 & 60,3 & 11,2 & 0,30 & 0,29 \\
\hline 11 & 9,4 & 38,4 & 72,1 & 62,7 & 12,8 & 0,29 & 0,28 \\
\hline 12 & 13,8 & 45,6 & 72,7 & 58,9 & 13,8 & 0,30 & 0,27 \\
\hline 13 & 14,4 & 46,3 & 77,4 & 63,0 & 17,5 & 0,29 & 0,23 \\
\hline
\end{tabular}

Les variations de $\sin 0=l\left(2 \pi y_{m} / b\right)$ sont représentées sur la figure 4 pour diverses valeurs de $F$, d'après les résultats des expériences 1-13 (grand canal Venturi) et $14 c$ (correspondant a $F=1$ ), $16 a-e$ et $14 \mathrm{~h}$ (correspondant à $1 / \mathrm{F}=1,65), 17 \mathrm{a}-\mathrm{h}$ et $14 \mathrm{c}$ (correspondant à $1 / F=0,655$ ). La concordance est bonne en général; mais pour le grand canal Venturi, les différences s'expliquent par l'imprécision des mesures, la grande pente de la surface libre et lapproximation de la valeur de $\mathrm{F}$.

Sur la figure 5 on a porté les valeurs de $\sin \theta$ (mesuré) en fonction de $\sin \theta$ (théorique) pour l'ensemble des expériences $1-13,14,15,16$ et 17 ; les points devraient se trouver sur une ligne droite faisant un angle de $45^{\circ}$ avec les axes. Les expériences réalisées englobent la plupart des cas pratiques : $0,3<\mathrm{F}<2,5 ; 0,2<y_{0} / b<3$ et $12^{\circ}<0<50^{\circ}$.

Les expériences relatées dans [1] p. 1348 ff étayent aussi la théorie pour les écoulements à grande vitesse correspondant a $F=3$ et $F=4$.

Les courbes de niveau théoricues calculées d'après (5) : $y_{0}^{\prime}=y_{m}+a \sin 2 \pi x / \lambda \cdot \cos 2 \pi z / \lambda$ (fig. 6) concordent de facon remarcuable avec les niveaux mesurés de la figure $37 \mathrm{~b}$ de l'article [1]. Il est bien certain qu'une telle surface libre apparaît à l'oeil comme formée d'ondes obliques, si on se reporte à la photographie (fig. 7) d'une maquette clablie d'après la figure 6 , prise en lumière rasante.

Les profils de la surface libre le long de la paroi
TABLEAU II

\begin{tabular}{|c|c|c|c|c|}
\hline $\begin{array}{l}\text { Exp. } \\
N^{\circ}\end{array}$ & $1 / \mathrm{F}$ & $2 \pi y_{m} / b$ & $\begin{array}{l}\sin \vartheta \\
\text { mes. }\end{array}$ & $\begin{array}{l}\sin \vartheta \\
\text { théor. }\end{array}$ \\
\hline $14 \mathrm{a}$ & ab. 0,40 & 3,5 & 0,22 & 0,21 \\
\hline b & ob. 0,53 & 4,2 & 0,27 & 0,26 \\
\hline c & 0,657 & 4,9 & 0,32 & 0,29 \\
\hline d & 0,785 & 5,1 & 0,38 & 0,33 \\
\hline e & 1,00 & $\tilde{0}, 9$ & 0,44 & 0,40 \\
\hline t & 1,25 & 6,9 & 0,48 & 0,48 \\
\hline$g$ & 1,32 & 7,2 & 0,50 & 0,47 \\
\hline $\mathrm{h}$ & 1,65 & 8,3 & 0,55 & 0,53 \\
\hline $\mathrm{i}$ & 2,11 & 9,8 & 0,63 & 0,61 \\
\hline j & 2,47 & 10,8 & 0,66 & 0,66 \\
\hline k & 2,85 & 11,9 & 0,73 & 0,70 \\
\hline 1 & 3,28 & 13,1 & 0,76 & 0,74 \\
\hline $15 \mathrm{~b}$ & ab. 0,36 & 2,3 & 0,26 & 0,23 \\
\hline $\mathrm{c}$ & 0,421 & 2,55 & 0,31 & 0,26 \\
\hline d & 0,546 & 3,0 & 0,35 & 0,31 \\
\hline e & 0,704 & 3,6 & 0,40 & 0,37 \\
\hline $\mathrm{f}$ & 0,851 & 4,1 & 0,43 & 0,41 \\
\hline$g$ & 1,10 & 4,8 & 0,45 & 0,47 \\
\hline $\mathrm{h}$ & 1,27 & 5,3 & 0,54 & 0,52 \\
\hline i & 1.52 & 6,0 & 0,57 & 0,57 \\
\hline $\mathrm{j}$ & 1.98 & 7,1 & 0,68 & 0,66 \\
\hline k & 2,59 & 8,5 & 0,74 & 0,73 \\
\hline $16 \mathrm{a}$ & 1,66 & 8,72 & 0,51 & 0,52 \\
\hline b & 1,65 & 7,60 & 0,55 & 0,55 \\
\hline $\mathrm{c}$ & 1,66 & 6,18 & 0,59 & 0,59 \\
\hline$d$ & 1,64 & 4,84 & 0,63 & 0,65 \\
\hline $\mathrm{e}$ & 1,66 & 3,50 & 0,71 & 0,73 \\
\hline $17 a$ & 0,655 & 4,85 & 0,26 & 0,28 \\
\hline b & 0,655 & 4,41 & 0,32 & 0,31 \\
\hline c & 0,654 & 3,97 & 0,34 & 0,32 \\
\hline d & 0,653 & 3,60 & 0,33 & 0,33 \\
\hline e & 0,655 & 2,51 & 0,38 & 0,40 \\
\hline f & 0,656 & 1,96 & 0,43 & 0,44 \\
\hline$g$ & 0,651 & 1,65 & 0,46 & 0,46 \\
\hline h & 0,660 & 1,29 & 0,53 & 0,51 \\
\hline
\end{tabular}


et au centre releyés dans [1] (fig. $38 \mathrm{c}$ et $46 a$ ) sont a peu près des sinusoïdes amorties. En partant de ces résultats, nous avons calculé $\lambda$ au moyen des équations (1) et (7) et comparé ces valeurs avec les valeurs mesurées. On constate, d'après le tableau I'I, que l'équation (7) constitue un très grand progrès.

TABJEAU III

\begin{tabular}{|c|c|c|c|c|c|c|c|c|}
\hline \multicolumn{5}{|c|}{ Donnes extraites de l'article [1] } & \multirow{3}{*}{$\frac{2 \pi h_{2}}{b_{2}}$} & \multicolumn{3}{|c|}{ Détermination de $\lambda$} \\
\hline \multirow[t]{2}{*}{$\mathrm{Fig} . \mathrm{No}$} & Section & $\mathrm{F}$ & $h$ & $b$ & & $\begin{array}{l}E_{q} \cdot(1) \\
\sin \vartheta=\frac{1}{F_{2}}\end{array}$ & $\begin{array}{c}\text { Eq. }(7) \\
\sin \vartheta= \\
f\left(\frac{2 \pi h_{2}}{b_{2}}, \frac{1}{F_{2}}\right)\end{array}$ & Exper. \\
\hline & & & $\mathrm{ft}$ & $\mathrm{ft}^{\mathrm{s}}$ & & $\mathrm{ft}$ & $\mathrm{ft}$ & $\mathrm{ft}$ \\
\hline \multirow{2}{*}{$\begin{array}{l}37(1), 38(c)(1) \\
46(t a), n, 49 \ldots\end{array}$} & 1 & 4,0 & 0,10 & 2,0 & & & & \\
\hline & 2 & 2,5 & 0,22 & 1,0 & 1,4 & 2,3 & 3,1 & 3,4 \\
\hline \multirow{2}{*}{$46(n) 11 \%$} & 1 & 3,0 & 0,10 & 2,0 & & & & \\
\hline & 2 & 1,5 & 0,25 & 1,0 & 1,6 & 1,1 & 1,9 & 2,0 \\
\hline \multirow{2}{*}{$46 a_{1} \cdot$} & 1 & 3,0 & 0,20 & 2,0 & & & & \\
\hline & 2 & 1,5 & 0,51 & 1,0 & 3,2 & 1,1 & 2,7 & 3,0 \\
\hline
\end{tabular}

Finalement, il ne reste à déterminer que $a$. Puisque cette surélévation provoque l'accélération centripète nécessaire, il semble raisonnable d'admettre que $a$ est proportionnel à $v^{2}$. Dès lors, le rapport $a /\left(v^{2} / 2 g\right)$ doit dépendre surtout de la forme de lentrée (et de la sortie), mais pour un canal Venturi donné ce rapport doit être le même pour tous les débits. La précision des mesures ne permet pas une étude plus serrée, mais on peut indiquer l'ordre de grandeur pour les expériences 1-10, c'est-à-dire pour $F=1$. En calculant le rapport des amplitudes maxima à la hauteur due à la vitesse à l'entrée $v_{i}^{2} / 2 g$, on obtient :

TABLEAU IV

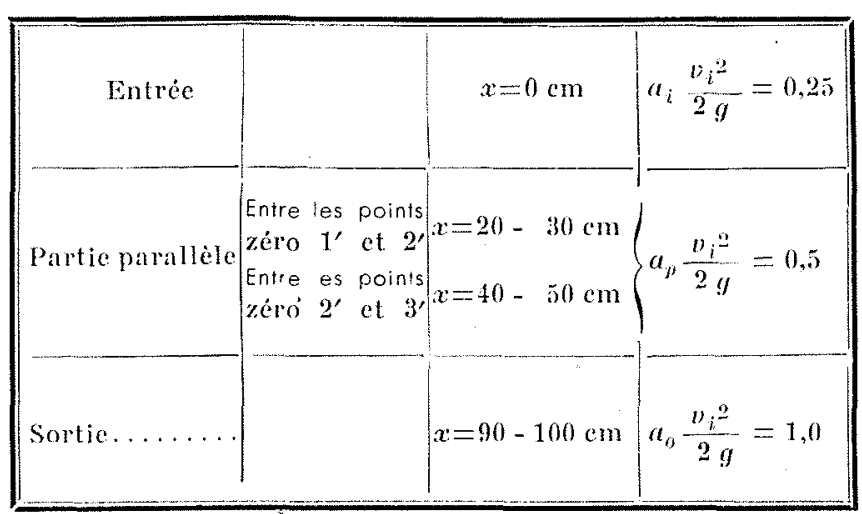

L'erreur moyenne est de 15-25\%.
RÉSEAU D'ONDES DANS UN CANAL DIVERGENT. ECOUIEMENT SUPRACRITIQUE.

D'après les expériences dont nous venons de parler, il semble donc qu'après une contraction en forme de $\mathrm{S}$ ce soit londe de deuxième ordre qui prédomine à la surface libre. A l'aval d'un canal divergent, par contre, les choses sont beaucoup plus compliquées et c'est dans le but d'éclaircir quelque peu la question que les expériences ci-après ont été réalisées.

A l'intérieur d'un canal de $60 \mathrm{~cm}$ de largeur, on a construit un canal en bois large de $37 \mathrm{~cm}$, comportant un raccordement parabolique, long de $45 \mathrm{~cm}$ et formant un angle de $20^{\circ}$ avec les parois du canal (voir la photographie, fig. 1). Le fond du canal en bois était surélevé de $5 \mathrm{~cm}$ an-dessus du fond du grand canal. Le débit mesuré au moyen d'un déversoir THomson était de $100,3 \mathrm{l} / \mathrm{s}$; les profils transversaux de la surface libre étaient relevés tous les $10 \mathrm{~cm}$ avec une pointe de mesure.

Quelques-uns des profils obtenus sont tracés sur la figure $8 \mathrm{a}$. La profondeur moyenne augmentait légèrement dans le sens de l'écoulement; sa valeur moyenne dans la zone étudiée était de $8,25 \mathrm{~cm}$.

En examinant ces résultats, on se rend immidiatement compte qu'une surface libre de ce genre ne saurait être représenté de facon satisfaisante par l'équation (5). La périodicité n'est pas très régulière et les profils sont beaucoup trop irrégulier's et pointus pour pouvoir être représentés par une 
courbe sinusoïdale unique; on peut donc concevoir qu'une expression de la forme de (8) conviendrait micux. Pour vérifier cette hypothèse, on a fait une analyse harmonique de tous les profils de la figure $8 a$; on a porté en fonction de $x$ les coefficients de Fourier obtenus de cette facon (fig. $8 \mathrm{~b}$ ). L'expression (8) ne.sera valable que si les courbes ainsi traces sont les sinusoïdes $a_{n} \sin 2 \pi x / \lambda_{n}$. Or, on constate d'après la figure $8 \mathrm{~b}$, que les courbes ont effectivement une allure très proche de la sinusoïde, bien qu'elles s'amortissent un peu, ce qui est peut-être dî au frottement qu'on a négligé. De plus, il est à noter que les amplitudes sont assez grandes, ce qui tend peut-être à augmenter l'écart entre les courbes et les sinusoïdes théoriques.

Les ondes du sixième ordre et d'ordres supérieurs sont très amorties et leur influence a presque complètement cessé de se faire sentir à quelques $2,50 \mathrm{~m}$ du divergent.

L'onde du deuxième ordre est celle qui se rapproche le plus de la sinusoüde. A vrai dire, l'amplitude de la première demi-période est un peu supérieure a celle des trois autres curi suivent; ceci est peutètre dû̀ à l'amortissement effectif mais peut aussi s'expliquer par l'imprecision plus grande des mesures du fait des grandes variations de la surface libre.

La périodicité des ondes des deuxième et quatrième ordres est très neltement marquée et on peut mesurer avec une bonne précision : $\lambda_{2}=1,44 \mathrm{~m}$ et $\lambda_{4}=0,90 \mathrm{~m}$. Pour le cas que nous venons d'étudier, le nombre de Froude est $\mathrm{F}=2,25$ et $2 \pi y_{m} / b$ $=0,864$. Par conséquent, les longueurs d'onde théoriques sont respectivement $\lambda_{2}=1,40 \mathrm{~m}$ et $\lambda_{4}=0,89 \mathrm{~m}$, valeurs qui concordent bien avec les résultats expérimentaux. Les angles $\theta$ correspondants sont respectivement $23^{\circ}, 1$ et $18^{\prime \prime}, 7$ alors que l'équation (1) donne $0=26^{\circ}, 4$.

L'onde du sixième ordre est moins régulière, ce qui peut vraisemblablement s'expliquer par le fait que la précision des courbes doit nécessairement diminuer lorsque l'ordre augmente. Toutefois, la période concorde bien avec la valeur théorique $(0,71 \mathrm{~m})$ sauf dans l'intervalle compris entre $x=1,40 \mathrm{~m}$ et $x=1,80 \mathrm{~m}$; cette différence provient peut-être de ce cul'il se forme de l'écume et des gouttelettes d'eau dans la zone qui précède (aux environs de $x=1,2 \mathrm{~m}$ ).

Une expérience analogue a été réalisée avec un canal divergent dont une seule paroi est en forme d'un $S$ (photographie de la fig. 9). Du point de vue théoricue, il ne devrait pas y avoir de différence fondamentale entre le cas du divergent unilatéral et celui du divergent symétrique, car on peut envisager l'écoulement dans le divergent unilatéral comme la moitié de l'écoulement symétrique dans un canal deux fois plus large. C'est ce que montre la figure 9 où la réflexion dans la paroi vitrée donne l'illusion d'un écoulement symétrique.

La figure 10 représente les profils de l'analyse harmonique de la surface libre dans ce cas. La principale différence entre ces résultats et ceux obtenus précédemment est qu'il n'y a pas trace d'un amortissement notable, compte non tenu de la première demi-période. Par conséquent, dans les limites de la précision des expériences, on peut remplacer les courbes par des sinusoïdes correspondant aux longueurs d'ondes $\lambda_{1}=2,4 \mathrm{~m}, \lambda_{2}=1,65 \mathrm{~m}$ et $\lambda_{3}=1,01 \mathrm{~m}$.
Le débit était de $448 \mathrm{l} / \mathrm{s}$ et la profondeur moyenne (qui augmentait légèrement dans le sens de l'écoulement) était de $0,28 \mathrm{~m}$ en moyenne; le nombre de Frover était donc $\mathrm{F}=1,608$ et $\pi y_{m} / b=1,466$. D'après l'équation (7), les longueurs d'onde auraient dû être $\lambda_{1}=2,28 \mathrm{~m}, \lambda_{2}=1,60 \mathrm{~m}$ et $\lambda_{3}=0,97 \mathrm{~m}$, chiffres qui diffèrent peu des valeurs expérimentales.

La théorie semble vérifiée d'une façon beaucoup plus nette par cette dernière expérience que par l'expérience précédente; c'est tout à fait normal, car celle-ci s'écarte beaucoup plus des hypothèses fondamentales que celle-là.

\section{CONCLUSION ET DISCUSSION DES RÉSULTATS.}

La principale conclusion qui se dégage des résultats précédents est que la simple équation (1) est un cas limite correspondant à l'écoulement à grande vitesse dans des canaux rectangulaires larges. Nous avons montré de plus que l'équation généralisée (7) (que nous avons établie) concorde bien avec les expériences anciennes et récentes réalisées pour une gamme étendue du nombre de Frovde $F$ et du paramètre $y_{m} / b$.

Il ressort de la démonstration théorique que nous avons donnée que l'on peut représenter le profil de la surface libre par une expression de la forme (8), c'est-à-dire en ajoutant un nombre infini d'ondes de différents ordres et de différentes longueurs d'onde. C'est ce qui explique l'absence d'une périodicité régulière et la courbure des fronts d'onde (voir fig. 9). Les résultats expérimentaux concordent bien avec la theorie; il $y$ a toutefois un amortissement plus ou moins prononcé des ondes, qui n'est pas prévu par la théorie.

Les hypotheses fondamentales qui sont à la base de la théorie semblent donc assez satisfaisantes. L'influence du frottement a déjà été signalée.

La tension superficielle ne jouerait un rôle important que dans de très petits canaux et nous n'avons pas recherché ses effets, bien que cela ne présente pas de sérieuses difficultés mathématiques.

Il serait du plus grand intérêt d'étudier une approximation du deuxième ordre, mais ce serait si compliqué que cela aurait probablement peu de valeur du point de vue pratique.

Mentionnons enfin les problèmes encore non résolus :

1. - Prévision de la grandeur des amplitudes lorsque sont donnés la forme des parois latérales et le débit.

2. - Position des ondes de différents ordres les unes par rapport aux autres.

3. - Calcul de l'amortissement.

4. - Influence de l'entraînement d'air.

Tous nos remerciements vont au professeur A.E. BretTring, directeur du Laboratoire d'Hydraulique, qui nous a autorisés à entreprendre ces expériences et a toujours porté un grand intérêt à nos recherches, ainsi qu'au professeur Dr. Richard PETenser, qui a bien voulu mettre l'analyseur harmonique à notre disposition. 